\title{
Steering microbiomes by organic amendments towards climate-smart agricultural soils
}

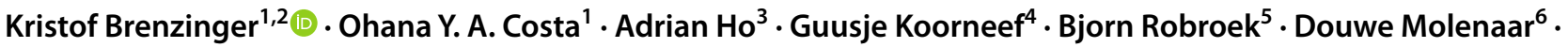 \\ Gerard Korthals ${ }^{1}$ · Paul L. E. Bodelier ${ }^{1}$
}

Received: 21 June 2021 / Revised: 6 September 2021 / Accepted: 17 September 2021 / Published online: 25 September 2021

(C) The Author(s) 2021

\begin{abstract}
We steered the soil microbiome via applications of organic residues (mix of cover crop residues, sewage sludge + compost, and digestate + compost) to enhance multiple ecosystem services in line with climate-smart agriculture. Our result highlights the potential to reduce greenhouse gases (GHG) emissions from agricultural soils by the application of specific organic amendments (especially digestate + compost). Unexpectedly, also the addition of mineral fertilizer in our mesocosms led to similar combined GHG emissions than one of the specific organic amendments. However, the application of organic amendments has the potential to increase soil C, which is not the case when using mineral fertilizer. While GHG emissions from cover crop residues were significantly higher compared to mineral fertilizer and the other organic amendments, crop growth was promoted. Furthermore, all organic amendments induced a shift in the diversity and abundances of key microbial groups. We show that organic amendments have the potential to not only lower GHG emissions by modifying the microbial community abundance and composition, but also favour crop growth-promoting microorganisms. This modulation of the microbial community by organic amendments bears the potential to turn soils into more climate-smart soils in comparison to the more conventional use of mineral fertilizers.
\end{abstract}

Keywords Greenhouse gases · Agricultural soils · Organic amendment · Flux measurements · Microbial community abundance and compositions $\cdot$ Plant growth

Kristof Brenzinger

kristof.brenzinger@uni-wuerzburg.de

1 Department of Microbial Ecology, Netherlands Institute of Ecology (NIOO-KNAW), , Wageningen, The Netherlands

2 Department of Animal Ecology and Tropical Biology, Biocenter, University of Würzburg, 97074 Würzburg, Germany

3 Institute of Microbiology, Leibniz Universität Hannover, 30419 Hannover, Germany

4 Department of Soil Chemistry and Chemical Soil Quality, Wageningen University, 6708 PB Wageningen, The Netherlands

5 Aquatic Ecology and Environmental Biology Group, Faculty of Science, Radboud Institute for Biological and Environmental Sciences (RIBES), , Radboud University, 6525XZ Nijmegen, The Netherlands

6 Systems Biology Lab, AIMMS, VU University, 1081HZ, Amsterdam, The Netherlands

\section{Introduction}

Atmospheric concentrations of the major GHG, carbon dioxide $\left(\mathrm{CO}_{2}\right)$, methane $\left(\mathrm{CH}_{4}\right)$, and nitrous oxide $\left(\mathrm{N}_{2} \mathrm{O}\right)$, have increased since the industrial revolution by $40 \%, 150 \%$, and 20\%, respectively (Sohngen and Tian 2016; IPCC 2018); approximately $50 \%$ and $60 \%$, respectively for $\mathrm{CH}_{4}$ and $\mathrm{N}_{2} \mathrm{O}$ of these GHG emissions originated from agriculture (Tian et al. 2016). The change in climate, in combination with other anthropogenic disturbances, has led to a tipping point of irreversible change in e.g. increased temperatures, loss of biodiversity, and eutrophication of global ecosystems (Steffen et al. 2018). In particular, $\mathrm{N}_{2} \mathrm{O}$ emission from agricultural soils is attributable to the intensive application of mineral/synthetic fertilizers (Sainju 2016; Tian et al. 2016; Kaupper et al. 2020a), which simultaneously causes environmental problems such as eutrophication of surface and groundwater and acidification of soils. Hence, current agricultural management practices urgently need to be transformed towards climate-smart sustainable agriculture. 
Climate-smart sustainable agriculture focuses on minimizing GHG emissions and increasing $\mathrm{C}$ sequestration while maintaining or even enhancing crop yield (Paustian et al. 2016). Therefore, there is an urgent demand for fertilizers that release nutrients in a more sustainable way, with lower eutrophication effects, build-up of soil C while still supporting plant growth. Green fertilizers constitute a stoichiometrically more balanced substrate on the one hand not only for the crops but also for feeding soil microbes that are the basis of the whole soil food web, thereby supporting soil quality in general (Hoffland et al. 2020). In order to support soil functions and maintain or even increase crop yields, combinations of organic and more mineral green fertilizers (like green manure) may bear this potential by providing an easily accessible fertilizer with long-lasting effects on soil quality (Tahat et al. 2020). However, the role of microbial diversity and functioning in these mixed fertilizer trials needs more exploration, given that microorganisms are crucial for a sustainable agricultural system, and constitute plant growth-promoting bacteria (PGPB) and fungi (PGPF) for example nitrogen-fixers (diazotrophs) (Hossain et al. 2017; Srinivasarao and Manjunath 2017; Doni et al. 2019) which can be exploited to increase crop production. Yet, systematic studies exploring the interplay between fertilizer composition, GHG emissions, soil microbes, and crop yields in agricultural soils are scarce and incomplete give the current knowledge on soil microbial communities.

In soils, nitrogen $(\mathrm{N})$ transformation is rapid as nitrification (oxidation of $\mathrm{NH}_{4}{ }^{+}$) and denitrification $\left(\mathrm{NO}_{3}{ }^{-}\right.$reduction) processes occur readily, resulting in the production and release of $\mathrm{N}_{2} \mathrm{O}$ by microorganisms (bacteria and fungi) from these soils (Butterbach-Bahl et al. 2013; Rohe et al. 2014; Keuschnig et al. 2020). While multiple microbial pathways exist that result in $\mathrm{N}_{2} \mathrm{O}$ production, only the complete denitrification to $\mathrm{N}_{2}$ by $\mathrm{N}_{2} \mathrm{O}$-reductase (nosZ)-carrying bacteria exists as a $\mathrm{N}_{2} \mathrm{O}$ sink in agricultural soils (Chapuis-Lardy et al. 2007). However, while bacterial species can act as an $\mathrm{N}_{2} \mathrm{O}$ sink, fungal species only possess NO-reductase to produce $\mathrm{N}_{2} \mathrm{O}$ (Higgins et al. 2018). Recently, it has been shown that both fungi and bacteria are involved in $\mathrm{N}_{2} \mathrm{O}$ production after plant residue amendment, whereas bacteria predominately contributed to $\mathrm{N}_{2} \mathrm{O}$ production after mineral fertilizer application (Yamamoto et al. 2017). Representatives of the newly discovered $\mathrm{N}_{2} \mathrm{O}$-reducing clade II (nosZII) have been postulated to turn soils into $\mathrm{N}_{2} \mathrm{O}$ sinks (Domeignoz-Horta et al. 2016; Hallin et al. 2018). Approximately $50 \%$ of denitrifiers in the $\mathrm{N}_{2} \mathrm{O}$-reducing clade II only possess the nos $\mathrm{Z}$ gene and could reduce $\mathrm{N}_{2} \mathrm{O}$ further to $\mathrm{N}_{2}$, without even producing $\mathrm{N}_{2} \mathrm{O}$ (Jones et al. 2014; Domeignoz-Horta et al. 2015). First experiments with soil amendments with a non-denitrifying nosZII strain decreased the emitted $\mathrm{N}_{2} \mathrm{O}$ and turned the soil into a $\mathrm{N}_{2} \mathrm{O}$ sink (Domeignoz-Horta et al. 2016). Interestingly, nosZII-harbouring denitrifiers increased in agricultural soil after amendment with organic fertilizers. However, whether this stimulation is attributable to substrate addition via fertilizer and/or residue-borne microorganisms remains unclear, as is most of the ecology of these clade II $\mathrm{N}_{2} \mathrm{O}$-reducers, even though understanding their ecological characteristics is important if they are used as a GHG reducing application in agricultural soils (Hallin et al. 2018). Additionally, a recent study showed that also the addition of copper $(\mathrm{Cu})$ together with mineral fertilizers may reduce the $\mathrm{N}_{2} \mathrm{O}$ emissions of agricultural fields, since $\mathrm{Cu}$ is essential for the $\mathrm{N}_{2} \mathrm{O}$-reductase (Shen et al. 2020).

Consumption of atmospheric $\mathrm{CH}_{4}$ in well-aerated upland soils is responsible for approximately $10 \%$ of the global $\mathrm{CH}_{4}$ sink (Saunois et al. 2016). However, the $\mathrm{CH}_{4}$ sink capacity in agricultural soils is 3 to 9 times lower compared to undisturbed upland soils (Ho et al. 2015). This is mainly caused by the effect of agricultural intensification and associated fertiliser use on the $\mathrm{CH}_{4}$-oxidizing bacteria (methanotrophs). For instance, the destruction of the soil's physical structure through tilling was shown to disturb $\mathrm{CH}_{4}$ gradients in soil, affecting the activity of the high-affinity methanotrophs (Hütsch 1998). Also, the use of N-rich fertilizers reduces atmospheric $\mathrm{CH}_{4}$ uptake, likely due to the competitive inhibition of ammonia on the $\mathrm{CH}_{4}$ monooxygenase which catalyses the first step of $\mathrm{CH}_{4}$ oxidation (Schnell and King 1994; Gulledge et al. 1997; Bodelier and Steenbergh 2014; Bodelier et al. 2019). These changes in agricultural practices can be long-lasting; the recovery of atmospheric $\mathrm{CH}_{4}$ uptake to pre-agriculture levels can take up to 80 years (Maxfield et al. 2008; Levine et al. 2011; Bodelier and Steenbergh 2014; Tate 2015). However, a recent study (Ho et al. 2015) demonstrated significantly enhanced $\mathrm{CH}_{4}$ uptake rates after the addition of organic amendments (e.g. compost, sewage sludge) to different agricultural soils; notably, the stimulated $\mathrm{CH}_{4}$ uptake rates were comparable to rates reported in wellaerated forest soils. Despite the importance of restoring the $\mathrm{CH}_{4}$ uptake potential of agricultural soils, research focusing on this aspect is scarce, presumably due to the anticipated low or negligible $\mathrm{CH}_{4}$ uptake potential in these soils as compared to (semi-)natural grassland and upland forest soils (Mosier and Delgado 1997; Ciais et al. 2009; Veldkamp et al. 2013).

In a previous study, we evaluated different organic amendments and combinations thereof for their potential to reduce GHG by promoting $\mathrm{CH}_{4}$ uptake and minimizing $\mathrm{CO}_{2}$ and $\mathrm{N}_{2} \mathrm{O}$ emissions (Brenzinger et al. 2018). Building on that knowledge, we designed this study in which we incorporate plants in order to assess the performance of organic amendments in two different agricultural soil types (sandy and clay soils) aiming at not only a favourable GHG balance by steering the microbial community but also maintain or increase crop yields by selective stimulation of the PGPB/PGPF. Specifically, we address the following research 
questions: (1) How can GHG emissions be reduced through the application of organic amendments without losing crop performance and how is crop growth itself affecting GHG; (2) How does organic fertilizer input influence microbial abundance and composition of microbial guilds involved in the $\mathrm{C}$ - and $\mathrm{N}$-cycle (methanotrophs, methanogens, nitrifiers, denitrifiers, diazotrophs), as well as the PGPB/PGPF; and what are the key (a)biotic factors controlling and shaping the microbial communities after the addition of organic amendments, and are changes in the microbial communities permanent? We hypothesize that the application of single or mixed organic fertilizers results in a more enriched and balanced microbial community, leading to lower GHG emissions without losing crop performance.

\section{Material and methods}

\section{Site description, soil sampling, and organic amendments}

Soils were collected in agricultural fields from the research station of Wageningen University in Lelystad (52 32' 26.4" $\left.\mathrm{N}, 05^{\circ} 33^{\prime} 34.7^{\prime \prime} \mathrm{E}\right)$ and Vredepeel $\left(51^{\circ} 32,032^{\prime \prime} \mathrm{N}, 05^{\circ}\right.$ $\left.50,054^{\prime \prime} \mathrm{E}\right)$ representing a marine clay and sandy soil, respectively. Detailed descriptions of the soils and soil sampling are provided in Online Resource 1. The residues included in this study were comprised of materials with a $\mathrm{C}: \mathrm{N}$ ratio ranging from 4.8 to 24.0 (Table 1) and were selected based on their performance in an earlier study (Brenzinger et al. 2018) or their common usage as bio-based additives in agricultural soil. Both soils and the residues were air-dried at $30{ }^{\circ} \mathrm{C}$ for minimal impact on their harbouring microorganisms. The soils were sieved $(2 \mathrm{~mm})$ prior to set up to ensure standardized initial incubation conditions. The sewage sludge (S) and digestate (D) were crushed and ground, prior to use. The compost (C) was crushed into larger pieces and sieved to $6 \mathrm{~mm}$ prior to use, while the cover crop residue mixture (Brassica carinata; Trifolium incarnatum; Secale cereal; 1:1:1) from November $2017\left(\mathrm{CC}_{\text {nov }}\right)$ and February $2018\left(\mathrm{CC}_{\mathrm{feb}}\right)$ were cut to smaller pieces $(\sim 1 \mathrm{~cm})$ before being applied to the soils.

\section{Mesocosm setup for in situ GHG flux measurements and $G W P_{100 y r}$ calculation}

The soil (1.6 kg dry weight) and each organic amendment were mixed in eight pots $22 \times 10 \mathrm{~cm}$ (diameter $\times$ height) and then watered with deionized water to $65 \%$ soil water holding capacity. The following residue treatments were applied $\mathrm{D}+\mathrm{C}$ (1:3 ratio), $\mathrm{S}+\mathrm{C}$ (1:3 ratio), $\mathrm{CC}_{\text {nov }}$, and $\mathrm{CC}_{\text {feb }}$ residue. The residue addition to the soil corresponded to a rate of 10 -ton $\mathrm{ha}^{-1}$, which is typically used in agricultural practice (Diacono and Montemurro 2010). Half of all treatments (+ P) were planted with five Triticum aestivum seeds; the other half received no seeds $(n=4)$. After germination of the seeds, all mesocosms were adjusted to four plants and were grown without further treatment. Two controls were used in the experiment, un-amended soil without a plant and soil with plant and application of grains of mineral fertilizer (MF; composition: $\mathrm{N}-\mathrm{NO}_{3} 6.6 \%, \mathrm{~N}-\mathrm{NH}_{4} 8.4 \%, \mathrm{P}_{2} \mathrm{O}_{5} 9 \%$; Osmocote

Table 1 Organic amendment and soil description, total C, and $\mathrm{N}$ contents of amendment and soil

\begin{tabular}{|c|c|c|c|c|}
\hline & $\begin{array}{l}\text { Total C (g C } \\
\text { kg dw sam- } \\
\left.\text { ple }^{-1}\right)\end{array}$ & $\begin{array}{l}\text { Total N (g N } \\
\text { kg dw sam- } \\
\left.\text { ple }^{-1}\right)\end{array}$ & $\mathrm{C}: \mathrm{N}$ & Description (source/location) \\
\hline \multicolumn{5}{|l|}{ Soil } \\
\hline $\begin{array}{l}\text { Clay soil (calcareous } \\
\text { clay) }\end{array}$ & $16.44 \pm 0.34$ & $1.12 \pm 0.07$ & 14.73 & $\begin{array}{l}\text { Clay soil from an agricultural field cropped with onions prior to sam- } \\
\text { pling. (Lelystad, The Netherlands) }\end{array}$ \\
\hline $\begin{array}{l}\text { Sandy soil (gleyed } \\
\text { podzol) }\end{array}$ & $22.20 \pm 3.04$ & $1.28 \pm 0.21$ & 17.30 & $\begin{array}{l}\text { Sandy soil from an agricultural field cropped with potatoes prior to } \\
\text { sampling (Vredepeel, The Netherlands) }\end{array}$ \\
\hline \multicolumn{5}{|l|}{ Organic amendments } \\
\hline Sewage sludge (S) & $202.74 \pm 12.82$ & $41.81 \pm 1.80$ & 4.85 & $\begin{array}{l}\text { Sampled from an anaerobic digester after sludge thickening } \\
\text { (Vallei Veluwe, The Netherlands) }\end{array}$ \\
\hline Digestate (D) & $290.07 \pm 14.14$ & $24.59 \pm 1.64$ & 11.80 & $\begin{array}{l}\text { Residue product of biogas formation from manure. (ACRRES, The } \\
\text { Netherlands) }\end{array}$ \\
\hline Compost (C) & $118.40 \pm 13.77$ & $6.25 \pm 0.65$ & 18.93 & $\begin{array}{l}\text { Van Iersel fungal dominant humic compost. Basic ingredient is wood } \\
\text { shreds. (Soiltech, The Netherlands) }\end{array}$ \\
\hline $\mathrm{CC}_{\text {nov }}$ residue mixture & $272.62 \pm 19.32$ & $31.97 \pm 1.70$ & 8.53 & $\begin{array}{l}\text { Consist of Brassica carinata, Trifolium incarnatum, Secale cereal } \\
\text { collected from a field in November 2017. (Joordens, The Netherlands) }\end{array}$ \\
\hline $\mathrm{CC}_{\mathrm{feb}}$ residue mixture & $361.90 \pm 22.20$ & $30.40 \pm 2.92$ & 11.91 & $\begin{array}{l}\text { Consist of Brassica carinata, Trifolium incarnatum, Secale cereal col- } \\
\text { lected from a field in February 2018. (Joordens, The Netherlands) }\end{array}$ \\
\hline
\end{tabular}

Measurements were performed in triplicate $($ mean \pm SD) 
Exact Mini 3-4 M, AICL, The Netherlands) (application rate: $175 \mathrm{~kg} \mathrm{~N} \mathrm{ha}^{-1}$ ). Subsequently, all mesocosms were incubated in a climate chamber at $15{ }^{\circ} \mathrm{C}$ (mean annual temperature in the Netherlands during the growing season) with 16-light per day for 64 days. Water loss, measured by weight, was compensated three times weekly. Periodically $\left(1,3,8,10,15,23,36,49,63\right.$ days), in situ $\mathrm{CH}_{4}, \mathrm{CO}_{2}$, and $\mathrm{N}_{2} \mathrm{O}$ fluxes were measured under ambient air by placing the mesocosm in a gas-tight transparent Plexiglas chamber (diameter $\times$ height: $24 \times 40 \mathrm{~cm}$ ). Samples were taken after $0,30,60$, and $90 \mathrm{~min}$, with an initial $30 \mathrm{~min}$ to allow gas flow to equilibrate the soil-headspace gas phase. During these time points, $30 \mathrm{~mL}$ of samples was taken out of the chambers and stored within a 6 -mL exetainer by first flushing the exetainers with $18 \mathrm{~mL}$ of sample followed by introducing $12 \mathrm{~mL}$ sample in the closed vial, creating an overpressure of 1 bar. A detailed description of the GHG measurement and calculation procedure are provided in the extended Material and method section in Online Resource 1. Since a transparent chamber was used, the GHG flux data only represent fluxes occurring during light hours. We calculated the cumulative GHGs of $\mathrm{CH}_{4}, \mathrm{CO}_{2}$, and $\mathrm{N}_{2} \mathrm{O}$ based on the $\mathrm{CO}_{2}$ equivalents ( $\mathrm{mg} \mathrm{kg}^{-1}$ soil) by combining the mean cumulative $\mathrm{CH}_{4}, \mathrm{CO}_{2}$, and $\mathrm{N}_{2} \mathrm{O}$ fluxes. In these calculations, the $\mathrm{CO}_{2}$ equivalent for $\mathrm{CH}_{4}$ and $\mathrm{N}_{2} \mathrm{O}$ is based on the GWP (100yr value and considered to be 28 and 265, respectively, over a hundred-year time frame, while the for $\mathrm{CO}_{2}$ is considered to be 1 (IPCC 2018).

\section{Sample storage, soil nutrient measurements, and plant growth determination}

During incubation, several sub samples were collected. At the start of the experiment, $100 \mathrm{~g}$ soil from each mesocosm was taken and stored in aliquots for further analyses. One aliquot was dried at $40{ }^{\circ} \mathrm{C}$ in an oven for determining soil nutrient composition and $\mathrm{pH}$, while another aliquot was stored in the $-20{ }^{\circ} \mathrm{C}$ freezer for DNA extraction. During the incubation, the soil was non-destructively sampled using a soil core (diameter $\mathrm{x}$ height: $3 \times 10 \mathrm{~cm}$ ) after 24 days and 49 days. At the end of the incubation, all soil was collected. The sampled soils were kept in aliquots as was performed during initial sampling.

On the same days of soil sample collection, we also measured the height of each wheat plant and counted the leaves. At the end of the incubation, the wheat plant was harvested and dried at $40{ }^{\circ} \mathrm{C}$, and the biomass was measured.

Nutrient concentrations in the soil samples $\left(\mathrm{NO}_{\mathrm{x}}{ }^{-}\right.$, exchangeable $\left.\mathrm{NH}_{4}{ }^{+}\right)$were determined in $1 \mathrm{M} \mathrm{KCl}(1: 5$ dilution) extract using a SEAL QuAAtro SFA autoanalyzer (Beun-de Ronde B.V. Abcoude, the Netherlands). Soil pH was determined in $1 \mathrm{M} \mathrm{KCl}$ (1:5 dilution) extracts.

\section{Measuring aggregate fractions}

After the incubation, water-stable aggregate fractions were separated via manual wet sieving (Six et al. 1999) to different fractions: large macroaggregates $(2-10 \mathrm{~mm})$, macroaggregates $(250-2000 \mu \mathrm{m})$, microaggregates $(53-250 \mu \mathrm{m})$, and the silt and clay fraction $(<53 \mu \mathrm{m})$. A detailed description of the wet sieving process and the aggregate measurement is provided in the extended Material and method section in Online Resource 1.

\section{DNA extraction and quantification of the structural gene abundances using qPCR assays}

DNA was extracted using the DNeasy PowerSoil Kit Pro (Qiagen, Venlo, The Netherlands) according to the manufacturer's instruction from each treatment. We performed qPCR assays targeting the nitrifier amoA gene for ammonium oxidizing Archaea (AOA)/Bacteria (AOB), nosZ clade I/II (nosZI and nosZII; $\mathrm{N}_{2} \mathrm{O}$-reducers), nirK and nirS $\left(\mathrm{NO}_{2}{ }^{-}\right.$-reducing denitrifiers), fnirk (fungal denitrification), nifH (N-fixers), mcrA (methanogens), and pmoA (methanotrophs). Each assay was performed in duplicate for each DNA extract with primers, primer concentration, and PCR profiles as shown in Online Resource 2. A detailed description of the qPCR protocol is provided in the extended Material and method section in Online Resource 1.

\section{Microbial community composition of different guilds involved in GHG production/ consumption analysed by amplicon sequence analyses}

DNA from the initial soil as well as from all 64 days treatment samples were selected for an Illumina MiSeqPE250 sequence analyses targeting universal fungal ITS region with primers ITS1f/ITS2, the V4 region of the 16S SSU rDNA of Archaea and Bacteria with the primer pair 515F/806R, the amoA of AOA with the primer pair arch-amoF/arch-amoR, the nosZI/II (denitrifiers) with primer pairs nosZ1F-mod/ nosZ2R-mod and nosZ-II-F/nosZ-II-R, respectively and the pmoA (methanotrophs) with the primer pair A189F/A682R, which also targets some AOB. A detailed overview of the primers can be found in Online Resource 3. The extracted DNA was sent to Genome Quebec Innovation Centre (Quebec, Canada) for further processing. A detailed overview of the processing of the sequencing data is provided in the extended Material and method section in Online Resource 1 . To calculate the $\alpha$-diversity and visualise the gene sequences, we used the phyloseq package version 1.30.0 in R (McMurdie and Holmes 2013). Raw sequences can be found at the European Nucleotide Archive under the accession number PRJEB43590 (http://www.ebi.ac.uk/ena/data/ view/PRJEB43590; available at 31.12.2021). 


\section{Statistical analyses of collected data}

All statistical analyses were done using $\mathrm{R}$ version 3.0.1 ( $\mathrm{R}$ Core Team 2018). The mean total GHG fluxes, the GWP, $\mathrm{NO}_{3}{ }^{-} / \mathrm{NH}_{4}{ }^{+}$concentrations, and abundance of the different structural marker genes were tested for normality by the Kolmogorov-Smirnov test and homogeneity of variance by Levene's test. If necessary, normal distribution was achieved by log-transformation of the data. The mean differences were assessed using one-way ANOVA followed by Tukey's post hoc test. All levels of significance were defined at $P<0.05$.

Differences/similarities in the composition of the different microbial communities were analysed using non-metric multidimensional scaling (NMDS). Non-metric multidimensional scaling (NMDS) analyses were performed with the Bray-Curtis similarity index, which iteratively plots the rank order of similarity of communities in a way that community point distances are exactly expressed in a two-dimensional plane. The reliability of the presentation was calculated by a stress value. Stress $<0.05$ provides an excellent representation in reduced dimensions, $<0.1$ very good, and $<0.2$ good. ANOVA and NMDS were executed using the package vegan version 2.5-7 (Oksanen et al. 2020).

We used structural equation modelling (SEM) to evaluate which factors influence the effect of the addition of organic amendments, on GHG emissions, microbial communities, and plant growth and how they potentially interact (Grace 2006). A detailed description of the SEM analyses is provided in the extended Material and method section in Online Resource 1.

Correlations between microbial abundance data at 24 days and 64 days and the respective measured GHG fluxes ( $\mathrm{N}$-cycling genes vs $\mathrm{N}_{2} \mathrm{O}$ and $\mathrm{C}$-cycle genes vs $\mathrm{CH}_{4}$ and $\mathrm{CO}_{2}$ ) were analysed in $\mathrm{R}$ with the ggpubr and the cor() function. To calculate correlations between the relative abundance of specific taxa from sequence data and our organic amendments, we fitted the normalized 16S rRNA gene sequence counts attributed at the family level to linear models of the amendment effects, treatment (wheat, no wheat), and soil type without interactions in $\mathrm{R}$ and calculated $P$ values and corresponding $q$-values (false discovery rate) using an ANOVA, filtering only those families that had $q$-values $<0.05$, resulting in a list of families with $5 \%$ false discovery rate. Subsequently, we investigated the functional microbial marker groups that are important for GHG balance, and additionally, we selected bacteria and fungi known to promote plant growth based on previous studies (Vessey 2003; Lucy et al. 2004; Hossain et al. 2017; Majeed et al. 2018). Additionally, we checked the ITS data on potential pathogenic fungi based on previous studies (Hannula et al. 2017).

\section{Results}

\section{Influence of organic amendment on consumption and production of GHG and inorganic $\mathrm{N}$}

All measured GHG fluxes were obtained during light hours and therefore reflecting not a complete day cycle assessment of the GHG fluxes.

Total measured $\mathrm{CH}_{4}$ fluxes in the clay soil varied between treatments (Fig. $1 \mathrm{~A}$ ) with the $\mathrm{D}+\mathrm{C}+\mathrm{P}$ showed the highest $\mathrm{CH}_{4}$ uptake, while the $\mathrm{MF}+\mathrm{P}$ and the unamended soils had the lowest uptake. The $\mathrm{CH}_{4}$ flux varied (Online Resource $4 \mathrm{~A}$ ) at the beginning of the experiment. After 24 days, all soils consumed $\mathrm{CH}_{4}$, but organic amendment nor the presence of plants affected $\mathrm{CH}_{4}$ fluxes. Cumulative mean $\mathrm{CH}_{4}$ uptake in the sandy soil (Fig. $1 \mathrm{~B}$ ) was higher in all amended soils compared to the unamended control and $\mathrm{MF}+\mathrm{P}$, except for the $\mathrm{D}+\mathrm{C}+\mathrm{P}$. $\mathrm{CH}_{4}$ uptake by the sandy soil was generally lower after the addition of organic amendments than $\mathrm{CH}_{4}$ uptake by the clay soil (Online Resource 4 B).

Total $\mathrm{CO}_{2}$ emissions were the highest in $\mathrm{CC}_{\mathrm{feb}}$-amended soil, followed by $\mathrm{CC}_{\text {nov }}$ (Fig. 1 C/D). Other amendments resulted in similar fluxes, irrespective of the soil type (Online Resource $4 \mathrm{C} / \mathrm{D}$ ). The presence of plants led to lower emissions of $\mathrm{CO}_{2}$. Also, the application of $\mathrm{D}+\mathrm{C}$ and $\mathrm{S}+\mathrm{C}$ led to an uptake of $\mathrm{CO}_{2}$ after a few weeks (Online Resource 4 C/D), which was likely caused by the presence of cyanobacteria developed on the soil surface.

The lowest total emitted $\mathrm{N}_{2} \mathrm{O}$ throughout the incubation in clay soil occurred in the un-amended soil $\left(\sim 3 \mathrm{mmol} \mathrm{m} \mathrm{m}^{-2}\right)$ followed by the $\mathrm{D}+\mathrm{C}$ treatments $\left(\sim 6-10 \mathrm{mmol} \mathrm{m}^{-2}\right)$, while the highest emissions were measured for the CC residues $\left(\sim 100-166 \mathrm{mmol} \mathrm{m}^{-2}\right)$. Overall, the total mean $\mathrm{N}_{2} \mathrm{O}$ emissions showed no difference between incubations with or without plants (Fig. 1 E). $\mathrm{N}_{2} \mathrm{O}$ fluxes showed a peak at 3 days and decreased gradually to almost zero emission after 36 days (Online Resource $4 \mathrm{E}$ ), except for the $\mathrm{S}+\mathrm{C}$ amendments, which peaked after 14 days of incubation. The highest fluxes were observed for both $\mathrm{CC}$ residues, while the un-amended soils displayed the lowest. In the sandy soil, the highest total mean emissions occurred for the $\mathrm{CC}_{\text {nov }}$ residue $\left(227 \mathrm{mmol} \mathrm{m}^{-2}\right.$ ), followed by the $\mathrm{CC}_{\mathrm{feb}}$ residue samples $\left(145 \mathrm{mmol} \mathrm{m}^{-2}\right)$, while the lowest emissions were measured in the un-amended soils $\left(8 \mathrm{mmol} \mathrm{m}^{-2}\right)$ and the $\mathrm{D}+\mathrm{C}$ amendments (17-21 $\mathrm{mmol} \mathrm{m}^{-2}$ ) (Fig. $1 \mathrm{~F}$ ). $\mathrm{N}_{2} \mathrm{O}$ fluxes exhibited a different trend than in the clay soil (Online Resource 4 F). Here, for all samples, the highest levels occurred after 21 days while emissions were almost zero after 49 days, except in the $\mathrm{CC}_{\text {nov }}$ residue samples, which still emitted $\mathrm{N}_{2} \mathrm{O}$ at the end of the incubation (Online 

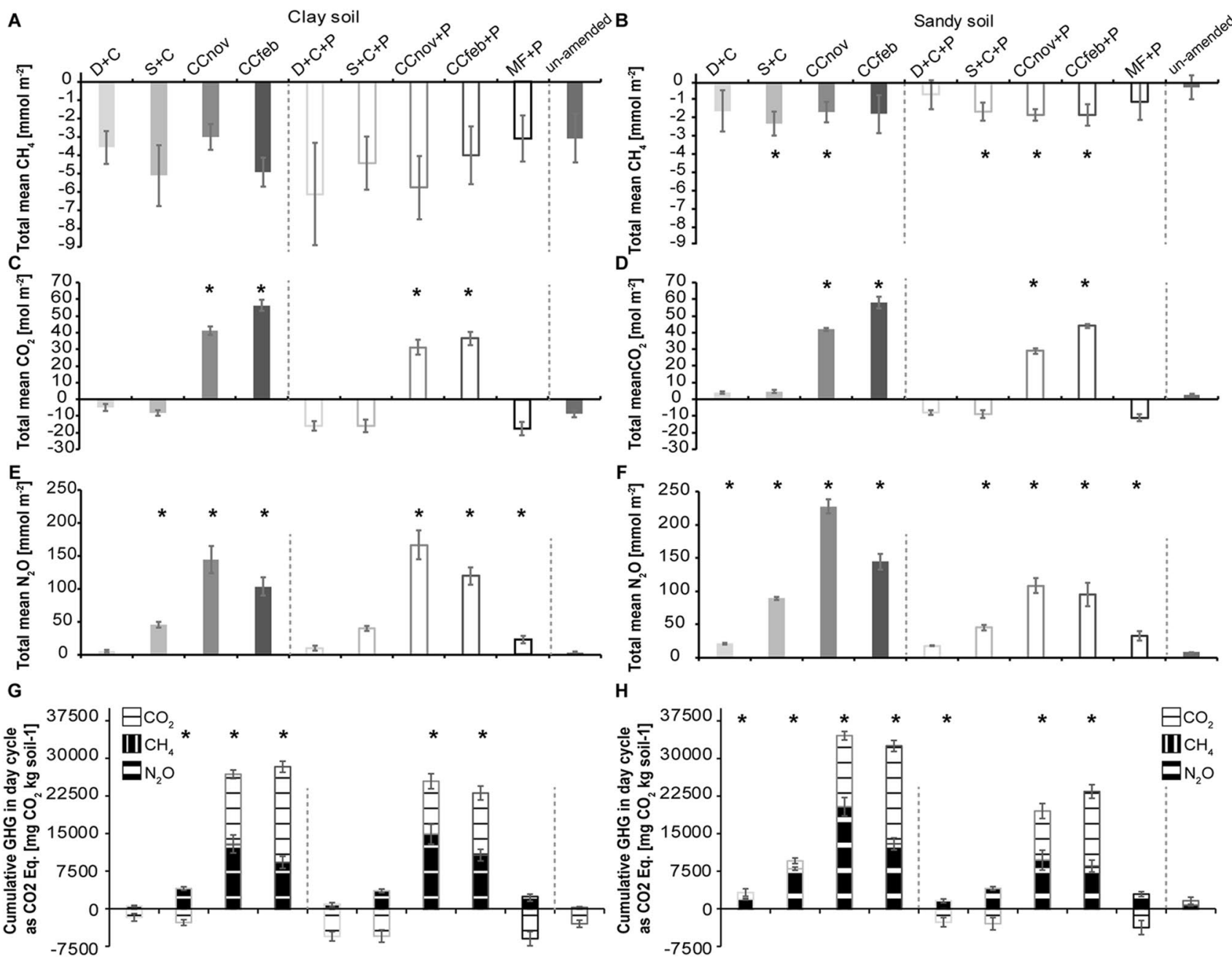

Fig. 1 Total mean $\mathrm{CH}_{4}(\mathbf{A}, \mathbf{B}), \mathrm{CO}_{2}(\mathbf{C}, \mathbf{D}), \mathrm{N}_{2} \mathrm{O}(\mathbf{E}, \mathbf{F})$, and cumulative GHG $(\mathbf{G}, \mathbf{H})$ emitted or consumed during daylight over the period of 65 days in clay $(\mathbf{A}, \mathbf{C}, \mathbf{E}, \mathbf{G})$ and sandy soil $(\mathbf{B}, \mathbf{D}, \mathbf{F}, \mathbf{H})$ and after amendments with digestate + compost $(\mathrm{D}+\mathrm{C})$, sewage sludge + compost $(\mathrm{S}+\mathrm{C}), \mathrm{CC}$ residues mixtures from November and February $\left(\mathrm{CC}_{\text {nov }}\right.$ and $\left.\mathrm{CC}_{\mathrm{feb}}\right)$, and mineral fertilizer (MF) with

Resource $4 \mathrm{~F})$. In contrast to the clay soil, the presence of plants led to a significant decrease in total mean $\mathrm{N}_{2} \mathrm{O}$ production in all samples in the sandy soil.

The combined cumulative GHG fluxes based on their $\mathrm{CO}_{2}$ equivalent were strongly influenced by the cumulative total $\mathrm{CO}_{2}$ fluxes, irrespective of the soil type (Fig. $1 \mathrm{G} / \mathrm{H}$ ). Notably, treatments with $\mathrm{D}+\mathrm{C}$ with/without plants and $\mathrm{MF}+\mathrm{P}$ gave similar results as the un-amended soil.

The starting concentration of $\mathrm{NO}_{3}{ }^{-}$varied between the amendments and the two soils (Online Resource 5 A/B). The concentrations of $\mathrm{NO}_{3}{ }^{-}$decreased in all samples until the end of incubation, with the exception of both $\mathrm{CC}$ residue samples without plants, which increased again after 24 days, reaching higher concentrations than the starting concentrations. In samples with organic amendments and wheat, and without plant growth $(+\mathrm{P})($ mean $\pm \mathrm{SD} ; n=4)$ derived from the cumulative average $\mathrm{CH}_{4}, \mathrm{CO}_{2}, \mathrm{~N}_{2} \mathrm{O}$ fluxes (Online Resource 5). In between the dashed lines are samples with and without plant growth. Asterisks $(*)$ indicate significant differences in the total mean between the un-amended soil and the other samples within one soil (ANOVA: $P<0.05$ )

$\mathrm{NO}_{3}{ }^{-}$was completely consumed after 50 days while in the soil with mineral fertilizer addition, $\mathrm{NO}_{3}^{-}$was produced towards the end of the incubation. In the sandy soil, the starting $\mathrm{NO}_{3}{ }^{-}$concentrations were lower than in the clay soil (Online Resource $5 \mathrm{~B}$ ). The $\mathrm{CC}_{\text {nov }}$ residue in the unplanted soil resulted in the highest concentration of $\mathrm{NO}_{3}{ }^{-}$. After 24 days, the $\mathrm{NO}_{3}{ }^{-}$concentrations in unplanted mesocosms increased, except for the $\mathrm{D}+\mathrm{C}+\mathrm{P}$ treatment. In contrast, it dropped to almost 0 in all planted mesocosms but continued to increase in the other samples.

Like for the $\mathrm{NO}_{3}{ }^{-}$concentrations, the initial concentration of exchangeable $\mathrm{NH}_{4}{ }^{+}$varied strongly between soil and organic amendment (Online Resource $5 \mathrm{C}$ ). Exchangeable $\mathrm{NH}_{4}{ }^{+}$concentrations in all samples in the clay soil decreased to below $2 \mathrm{mg} \mathrm{kg} \mathrm{soil}{ }^{-1}$ during the first 24 days of incubation 
and stayed around these values until the end of the incubation. The only exception were the samples with $\mathrm{MF}+\mathrm{P}$, which varied between 4 and $10 \mathrm{mg} \mathrm{kg} \mathrm{soil}{ }^{-1}$ over the incubation. The exchangeable $\mathrm{NH}_{4}{ }^{+}$concentrations in the sandy soil were on average higher than in the clay soil (Online Resource 5 D); it decreased in all mesocosms amended with $\mathrm{D}+\mathrm{C}$ and $\mathrm{S}+\mathrm{C}$ in the first 24 days, while it increased in all other treatments. After 51 days, $\mathrm{NH}_{4}{ }^{+}$concentrations decreased in all mesocosms to below $10 \mathrm{mg} \mathrm{kg} \mathrm{soil}{ }^{-1}$, except for the MF + $\mathrm{P}$ sample, which increased to around $53 \mathrm{mg} \mathrm{kg}$ soil $^{-1}$. At the end of incubation, ammonium concentrations in mesocosms without plants started to increase again, while in the planted mesocosms, concentrations remained stable or decreased further.

\section{pH measurement and aggregate fractions}

The $\mathrm{pH}$ values were mainly affected by the soil type (Online Resource 6), in which the clay shows a circumneutral value during the whole incubation (7-8), while the $\mathrm{pH}$ values of the sandy were more acidic (5-6). The organic amendments did not have a major effect on the $\mathrm{pH}$ value in both soils.

The mean diameter weight (MDW) of the aggregate fraction stability was highly influenced by the soil type (Online Resource 7), in which the clay soil always showed higher values compared to the sandy soil. This corresponded with a different proportion of the different aggregate size fractions in the samples (Online Resource $8)$. While the clay soil contained a higher amount of smaller aggregates $(<53 \mu \mathrm{m}$ and 53-250 $\mu \mathrm{m})$, the sandy soil contained a higher portion of bigger aggregates $(250-2000 \mu \mathrm{m})$. The presence of a plant led to an increase of larger fractions in the clay soil and a decrease in the sandy soil. The different treatments did not have a significant effect on aggregate stability.

\section{Influence of organic amendment on plant growth}

The addition of $\mathrm{CC}$ residues led to an increase in plant growth for both soil types at the end of the incubation as compared to the incubations with $\mathrm{MF}+\mathrm{P}$ (Fig. 2). The $\mathrm{D}+\mathrm{C}$ and $\mathrm{S}+\mathrm{C}$ showed similar growth of wheat compared to the $\mathrm{MF}+\mathrm{P}$ treatment in the clay soil, while the $\mathrm{D}+\mathrm{C}$ amendment in the sandy soil led to less well-performing plants compared to $\mathrm{MF}+\mathrm{P}$.

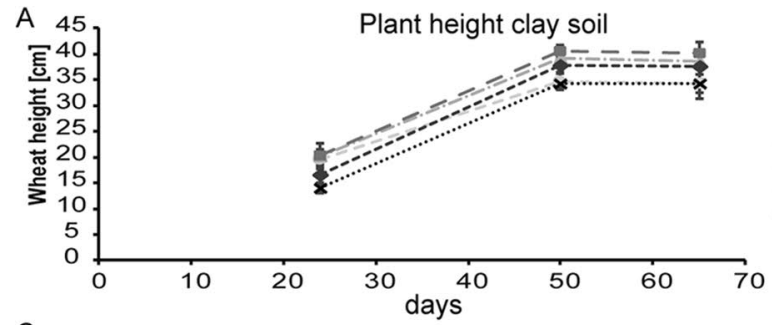

C
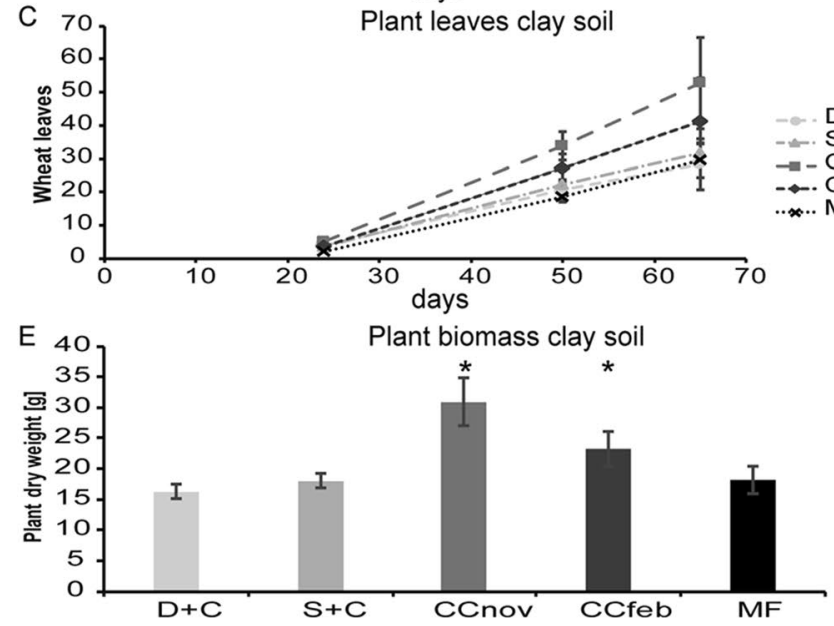

Fig. 2 Changes in wheat growth parameters: Wheat height in clay (A) and sandy loam soil (B) and number of leaves (clay: C; sandy loam: D) between 21 and 65 days, and wheat dry weight (clay: E; sandy loam: F), at the end of the experiment (65 days). Asterisks (*) indicate significant differences in wheat dry weight
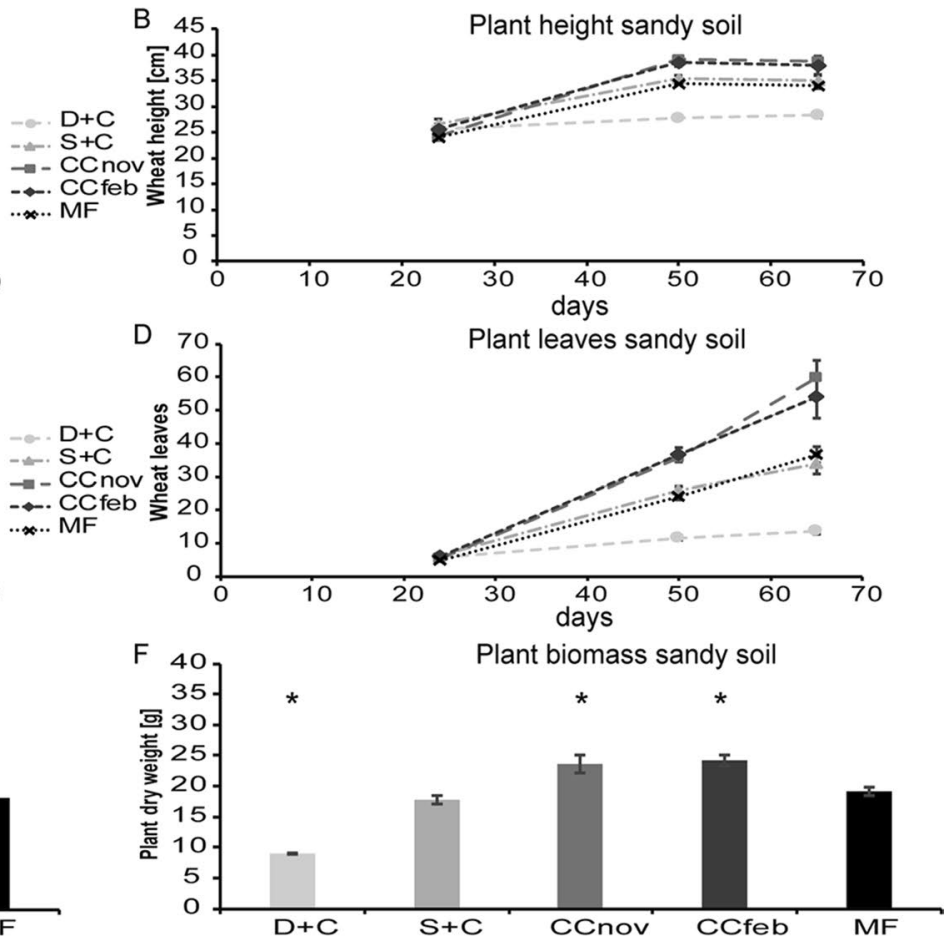

between the organic amendments and the MF amended soil (ANOVA: $P$ value $<0.05$ ). $\mathrm{D}+\mathrm{C}$, digestate + compost; $\mathrm{S}+\mathrm{C}$, sewage sludge + compost; CCnov, cover crop residues harvested in November 2017; CCfeb, cover crop residues harvested in February 2017; MF, mineral fertilizer (mean $\pm \mathrm{SD} ; n=4)$ 


\section{Abundance of microorganisms involved in GHG production and consumption}

To assess changes in the abundance of functional genes of different microbial guilds involved in the $\mathrm{N}$ - (nitrifiers, denitrifiers, $\mathrm{N}$-fixers) and $\mathrm{C}$-cycle (methanotrophs, methanogens) with the importance for GHG reduction or production, we calculated the ratio between gene copy numbers of the analysed genes in the initial soil after 24 and 64 days.

The abundance of these guilds was mainly influenced by soil type (Figs. 3 and 4 and Online Resource 9), but also organic amendment, plant growth, and time point of sampling affected the abundance of the different functional guilds, although not in a similar way. For example, D + C and $\mathrm{S}+\mathrm{C}$ addition led to a strong increase in abundance of
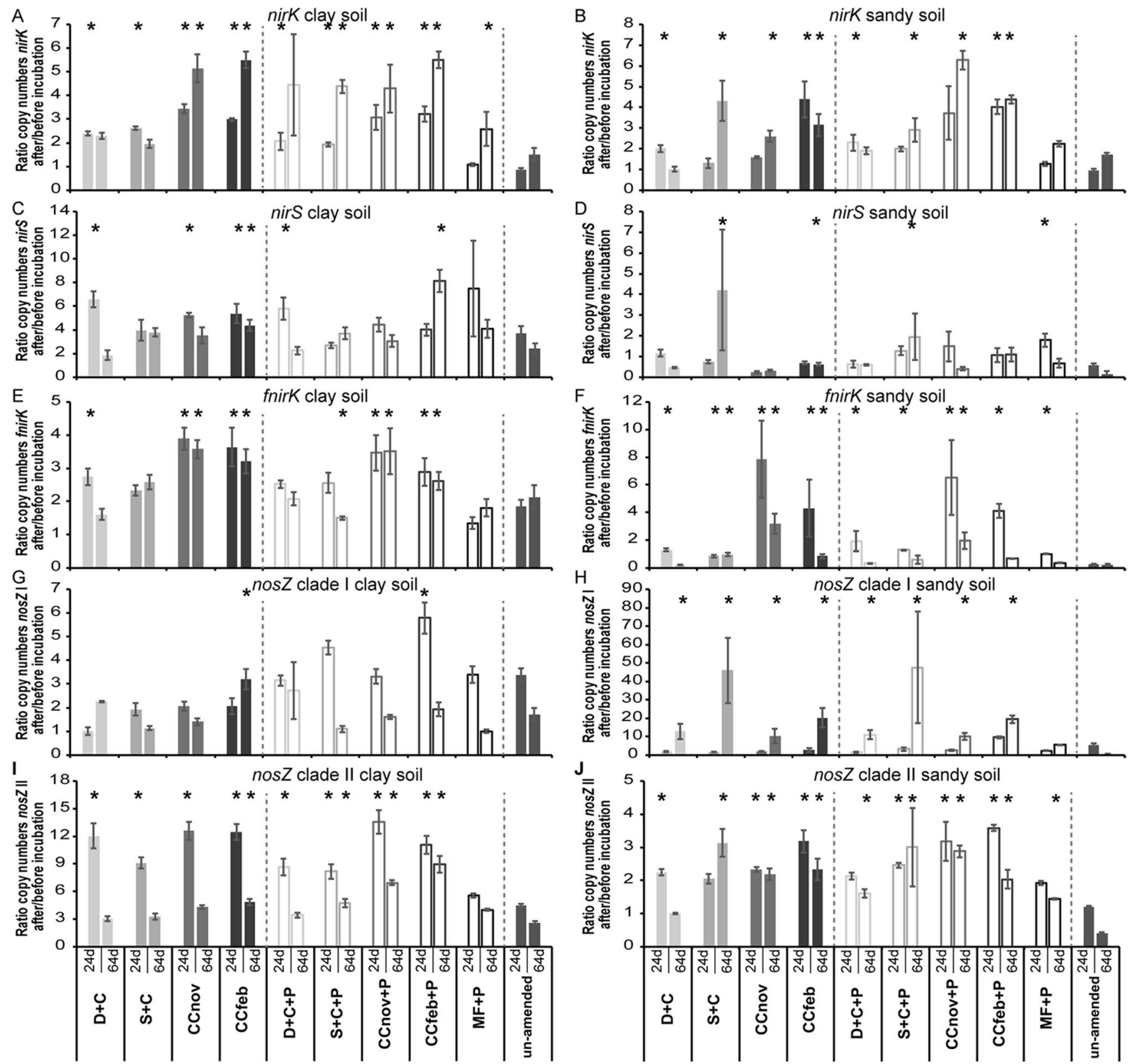

Fig. 3 Ratio of the copy numbers of the functional marker genes nirK $(\mathbf{A}, \mathbf{B}), \operatorname{nirS}(\mathbf{C}, \mathbf{D})$, fnirk (E, F), nosZ clade I (G, H), and nos $Z$ clade II (I, J), after 24 days/65 days and before incubation of clay (A, C, D, $\mathbf{E}, \mathbf{G}, \mathbf{I})$ and sandy $(\mathbf{B}, \mathbf{D}, \mathbf{F}, \mathbf{H}, \mathbf{J})$ soil and during amendments with digestate + compost $(\mathrm{D}+\mathrm{C})$, sewage sludge + compost $(\mathrm{S}+\mathrm{C}), \mathrm{CC}$ residues mixtures from November and February $\left(\mathrm{CC}_{\text {nov }}\right.$ and $\left.\mathrm{CC}_{\mathrm{feb}}\right)$

and mineral fertilizer (MF) with and without plant growth $(+\mathrm{P})$ (mean $\pm \mathrm{SD} ; n=4$ ) for 28 days. In between the dashed lines are samples with and without plant growth. Asterisks $(*)$ indicate significant differences in the mean total between the un-amended soil and the other samples within one soil and for one functional marker gene at a given time (ANOVA: $P<0.05$ ) 


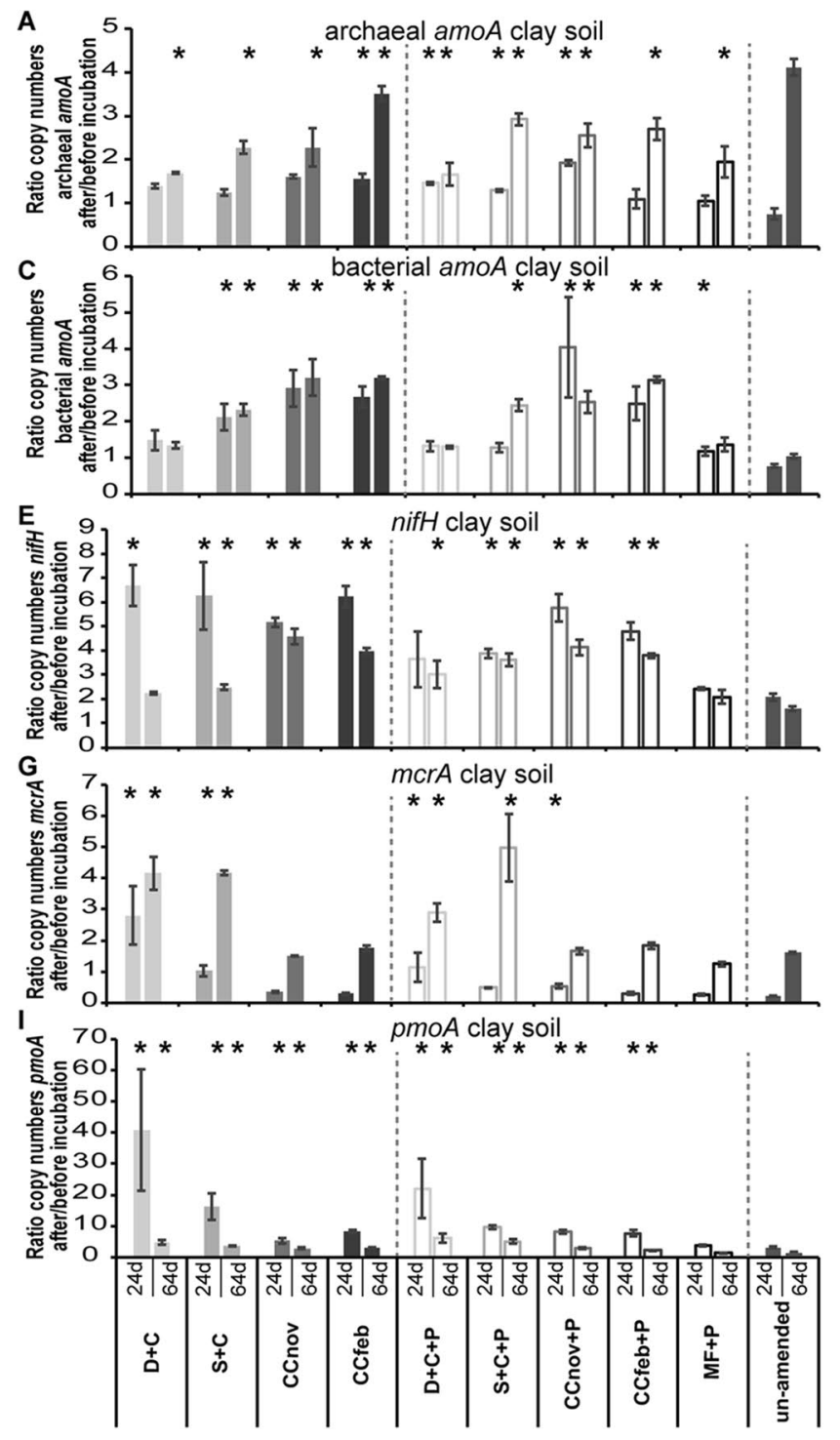

Fig. 4 Ratio of the copy numbers of the functional marker genes archaeal amoA (A, B), bacterial amoA (C, D), nifH (E, F), mcrA (G, H), and pmoA (I, J), after 24 days / 65 days and before incubation of clay $(\mathbf{A}, \mathbf{C}, \mathbf{D}, \mathbf{E}, \mathbf{G}, \mathbf{I})$ and sandy $(\mathbf{B}, \mathbf{D}, \mathbf{F}, \mathbf{H}, \mathbf{J})$ soil and during amendments with digestate + compost $(\mathrm{D}+\mathrm{C})$, sewage sludge + compost $(\mathrm{S}+\mathrm{C}), \mathrm{CC}$ residues mixtures from November and February

methanotrophs and methanogens (Fig. 4 G-J), while only a minor increase was observed after application of other amendments. The growth of methanogens was 10x higher in the clay soil. Organic amendments also increased the abundance of denitrifiers and bacterial nitrifiers in both soils compared to $\mathrm{MF}+\mathrm{P}$ and unamended soil treatment, with the highest increase with $\mathrm{CC}$ residue addition (Fig. 3). In contrast, organic amendments led to a decrease in archaeal nitrifiers. However, overall, organic amendments stimulated the growth of microbial guilds involved in GHG fluxes, which were most pronounced in clay soil with the $\mathrm{D}+\mathrm{C}$ amendment and with CC residues in the sandy soil. In both soils,

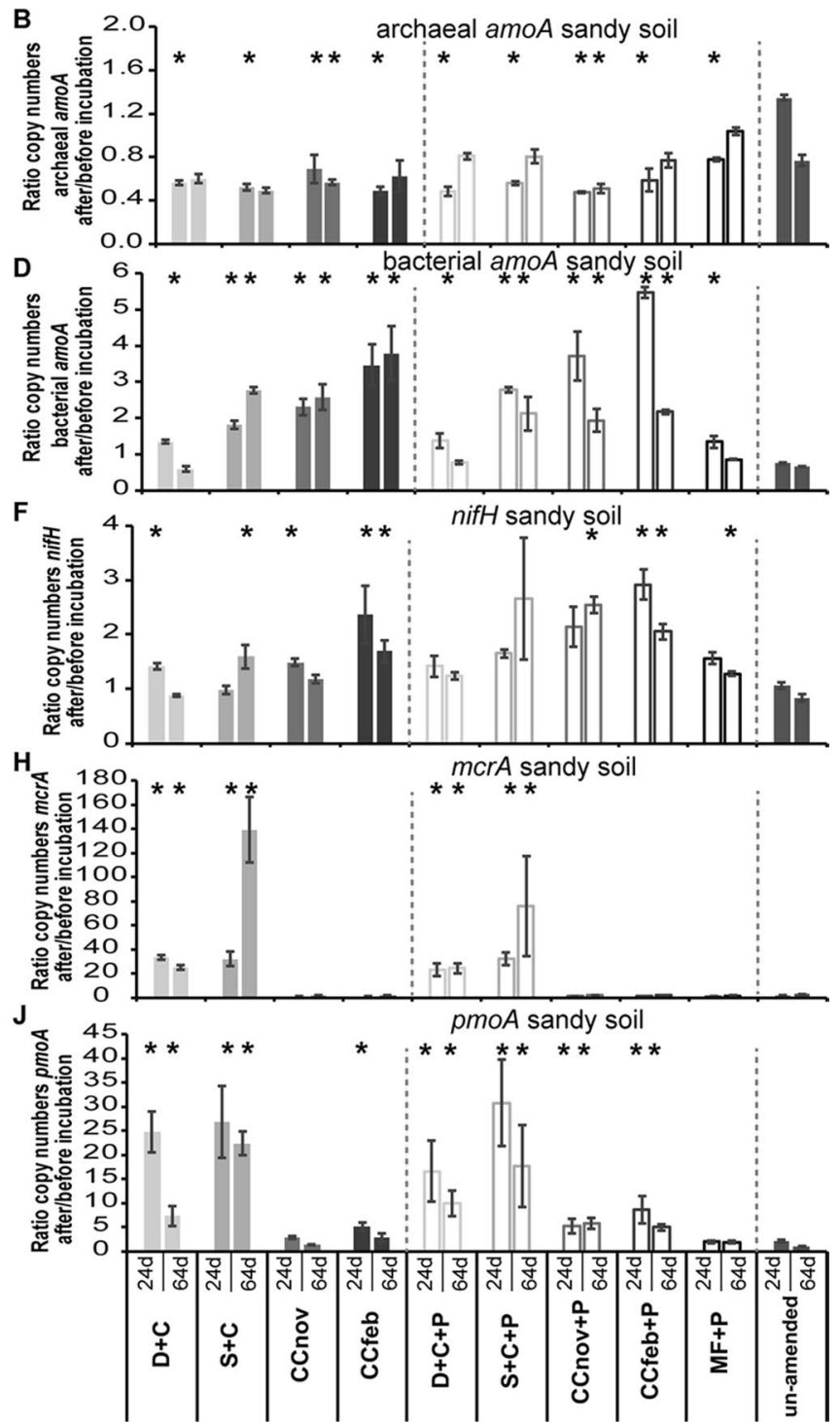

(CCnov and CCfeb) and mineral fertilizer (MF) with and without plant growth $(+\mathrm{P})($ mean $\pm \mathrm{SD} ; n=4)$ for 28 days. In between the dashed lines are samples with and without plant growth. Asterisks (*) indicate significant differences in the mean total between the unamended soil and the other samples within one soil and for one functional marker gene at a given time (ANOVA: $P<0.05$ )

the addition of MF did either not affect microbial guilds involved in GHG fluxes or even led to a reduction, which is in sharp contrast with the effect observed for the organic amendments. A more detailed overview of all changes that occurred during the experiment with respect to microbial abundances can be found in the extended Result section in Online Resource 10.

Correlation analyses of the abundance of the different microbial groups vs. the measured GHG fluxes showed that at 24 and 65 days only AOB $\left(R^{2}=0.66\right.$ and 0.63 , respectively) and $\operatorname{nos} Z I I\left(R^{2}=0.53\right.$ and 0.67 , respectively) showed a moderate to strong positive correlation to the measured 
$\mathrm{N}_{2} \mathrm{O}$ fluxes, while all other correlation analyses had a low $R^{2}$ score $(<0.3)$.

\section{Changes in microbial community composition}

\section{Correlation of individual taxa with effect of organic amendment application on overall community composition}

Correlation of individual taxa with a linear effect model of organic amendments effects on community composition showed varying positive and negative correlations with functional microbial groups involved in GHG emissions (Table 2). We detected a strong positive correlation ( $q$ value $<0.001$ ) of methanogens (e.g. Methanoculleus, Methanosarcina), an anaerobic nitrate-dependent methanotroph (Candidatus Methanoperedens), and aerobic Methylocaldum-like methanotroph with the application of compost. While the positive correlation ( $q$ value $<0.001$ ) of methanogens was stronger in combination with sewage sludge, methanotrophs were equally correlated $(q$ value $<0.001)$ with the $\mathrm{D}+\mathrm{C}$ and $\mathrm{S}+\mathrm{C}$ treatment. We observed the highest number of correlations between amendment and microbes for the nosZI denitrifiers. Especially, the $\mathrm{CC}_{\text {nov }}$ residue led to a strong positive correlation of a variety of clade I $\mathrm{N}_{2} \mathrm{O}$-reducers (e.g. Achromobacter, Agrobacterium, Brachymonas, Pseudomonas, and Rhizobiaceae). Also, other organic amendments showed positive correlations with nosZI microorganisms (e.g. Nitrospirillum, Ochrobactrum, Rhizobiales, and Rhizobium), while the $\mathrm{MF}+\mathrm{P}$ and unamended soil treatment only showed a few positively correlated taxa. For nosZII, we only observed three correlations with our treatments. While $\mathrm{S}+\mathrm{C}$ did not correlate with this group, all three $\mathrm{N}_{2} \mathrm{O}$-reducers (Adhaeribacter, Flavobacterium, and Rhodothermaceae) correlated with the $\mathrm{CC}_{\text {nov }}$ residue. AOA and AOB only showed negative correlations with the applied treatments.

Focusing on the correlation of organic amendment and plant growth-promoting bacteria (PGPB) and fungi (PGPF), we observed a strong increase in PGPB in the CC residue and the $\mathrm{S}+\mathrm{C}$ amendment (Table 3). While we identified 18 PGPB, only four PGPF were detected, and in three cases, these correlations were negative.

\section{Changes in microbial community composition after organic amendment application}

Generally, the 16S rRNA genes (bacterial and archaeal), ITS, archaeal amoA, pmoA, and bacterial amoA, nosZI, and nosZII gene diversity were specific to soil type, as revealed by the NMDS analyses (Fig. 5). While in the clay soil the bacterial/ archaeal 16S, the fungal ITS, the archaeal amoA, and the nosZI communities cluster together, all other communities in the clay soil and in the sandy soil were more dispersed, with a separation based mainly on the organic amendment applied (Fig. 5). These findings were supported by the PERMANOVA analyses (Online Resource 11), in which most variances were explained by soil type ( $P$ value $<0.001 ; R^{2}=0.30$ (ITS) -0.63 (nosZII). The addition of organic residues was significant (except for nosZII) but did not explain as much of the variance as the soil type ( $P$ value $\left.<0.01 ; R^{2}=0.06-0.24\right)$ while the presence of a plant mostly did not explain a significant part of the variance in community composition ( $P$ value $\left.>0.05 ; R^{2}=0.01-0.04\right)$. However, when the soils are separately analysed, the separation based on the treatment becomes more prominent (Online Resource 12 and 13). PERMANOVA was calculated separately for the two soil types (Online Resource 11), and it demonstrated that the organic amendment is the main factor for separation between the different samples in the clay soil $\left(R^{2}=0.25-0.62\right)$ and the sandy soil $\left(R^{2}=0.19-0.53\right)$. A detailed overview of the changes in the relative abundance of different genera and a more detailed description can be found in Online Resource 10.

\section{Discussion}

Our study highlights that the application of organic residues and mixes thereof can stimulate the soil microbial community with both benefits for GHG fluxes as well as plant growth. Especially amendment with digestate + compost $(D+C)$ leads to a reduction of GHG fluxes in two agricultural soils (clay and sandy) with the potential to increase soil $\mathrm{C}$, which is not the case when using mineral fertilizer (MF). While GHG emissions from cover crop (CC) residues were higher compared to MF, crop growth in both soil types was promoted. Furthermore, organic amendment caused a shift in the diversity and abundances of groups of soil microorganisms and specifically increased the abundance of PGPB/ PGPF, whereas MF did not lead to changes in the microbial community.

\section{Can GHG emissions from fallow and planted agricultural soils be reduced through the application of organic amendments without reducing crop performance?}

\section{Greenhouse gas emissions and total mean cumulative GHG emissions}

The total mean cumulative GHG emission, measured during light hours (in $\mathrm{CO}_{2} \mathrm{Eq}$.), was primarily composed of $\mathrm{CO}_{2}$, and to a lesser extent $\mathrm{N}_{2} \mathrm{O}$, particularly in the sandy soil, while in our experiment $\mathrm{CH}_{4}$ had a minor effect on the total mean cumulative GHG emission since its uptake only increased at the end of our experiment in the compost 
Table 2 Correlation analyses of microbial groups involved in GHG balance and the different organic amendments

\begin{tabular}{|c|c|c|c|c|c|c|c|}
\hline Gene & Correlated organisms & $\mathrm{D}+\mathrm{C}$ & $\mathrm{S}+\mathrm{C}$ & CCnov & CCfeb & MF & Unamended \\
\hline \multirow[t]{7}{*}{ Archaeal $16 \mathrm{~S}$} & Candidatus Methanoperedens & & $+^{*}$ & & & & \\
\hline & Methanobacterium & $+* *$ & $+* * *$ & & & & \\
\hline & Methanobrevibacter & & $+* * *$ & & & & \\
\hline & Methanoculleus & $+* *$ & $+* * *$ & & & & \\
\hline & Methanomassiliicoccus & $+* *$ & $+*$ & & & & \\
\hline & Methanosarcina & $+* * *$ & $+* * *$ & & & & \\
\hline & Methanosphaera & & $+*$ & & & & \\
\hline \multirow[t]{5}{*}{ Archaeal $a m o A$} & Nitrosopumilales-Eta & $-* *$ & $-* *$ & $-* * *$ & $-* *$ & $-*$ & $-* *$ \\
\hline & Nitrososphaerales-Alpha & & & & & $-*$ & \\
\hline & Nitrososphaerales-Beta & & & & & $-*$ & \\
\hline & Nitrososphaerales-Delta & & & $-*$ & & $-* * *$ & \\
\hline & Nitrososphaerales-Zeta & $-*$ & $-*$ & & & & \\
\hline pmoA/ & Cluster 1amoA/pmoA (COMMAMOX) & & $-*$ & $-* *$ & $-* * *$ & $-*$ & $-*$ \\
\hline pmoA like/ & Methylocaldum-like & $+* * *$ & $+* * *$ & & & & \\
\hline \multirow[t]{2}{*}{ bacterial $a m o A$} & Mycobacterium & $+* * *$ & & & & & \\
\hline & Nitrosospira (no COMMAMOX) & $-* * *$ & $-* * *$ & $-* * *$ & $-*$ & $-* *$ & \\
\hline \multirow[t]{34}{*}{ nos $Z$ clade I } & Achromobacter & & & $+* * *$ & $+*$ & & \\
\hline & Agrobacterium & & & $+* * *$ & $+*$ & & \\
\hline & Alcaligenes & & $+^{*}$ & & & & \\
\hline & Alphaproteobacteria clade I & & & $+* * *$ & $+* *$ & & \\
\hline & Aromatoleum & $+* *$ & $+^{*}$ & $+* * *$ & $+^{*}$ & $+* *$ & \\
\hline & Azospirillum & & & & & & $+* *$ \\
\hline & Bauldia & & & $+* * *$ & $+^{*}$ & & \\
\hline & Bordetella & & & & & $+^{*}$ & \\
\hline & Brachymonas & & & $+* * *$ & & & \\
\hline & Bradyrhizobiaceae & $+* * *$ & & & & & $+*$ \\
\hline & Bradyrhizobium & $+*$ & & & & & \\
\hline & Burkholderia & $+* *$ & $+*$ & $+* * *$ & $+*$ & $+^{*}$ & \\
\hline & Cereibacter & $+* * *$ & $+* *$ & $+* * *$ & $+*$ & $+* *$ & \\
\hline & Devosia & & & $+* * *$ & $+*$ & & \\
\hline & Ensifer & & & $+* * *$ & $+^{*}$ & & \\
\hline & Environmental samples clade I & $+* *$ & $+^{*}$ & $+* * *$ & $+*$ & $+^{*}$ & \\
\hline & Hydrogenophaga & $+*$ & & & & & \\
\hline & Hyphomicrobium & & $+* * *$ & & & & \\
\hline & Luteimonas & $+*$ & & & & & \\
\hline & Nitrospirillum & $+* *$ & $+*$ & & & & \\
\hline & Novimethylophilus & & & $+* *$ & $+* *$ & & \\
\hline & Ochrobactrum & & & $+* * *$ & $+* * *$ & & \\
\hline & Oligotropha & & $+* * *$ & & & & \\
\hline & Pseudomonas & & & $+* *$ & & & \\
\hline & Pusillimonas & & & $+* *$ & & & \\
\hline & Rhizobiaceae & & & $+* * *$ & & & \\
\hline & Rhizobiales & $+* * *$ & $+* *$ & $+* * *$ & $+* *$ & & \\
\hline & Rhizobium/Agrobacterium group & $+* * *$ & $+*$ & $+* * *$ & $+*$ & & \\
\hline & Rhizobium & $+* *$ & $+*$ & $+* * *$ & $+^{*}$ & & \\
\hline & Rhodospirillaceae & $+*$ & & & & & \\
\hline & Shinella & & & $+* *$ & & & \\
\hline & Thauera & & $+*$ & & & & \\
\hline & Uncultured nos $Z$ clade I bacterium & $+* * *$ & $+^{*}$ & $+* *$ & $+*$ & & $+* *$ \\
\hline & Zoogloeaceae & $+* * *$ & & & & $+* * *$ & $+* *$ \\
\hline
\end{tabular}


Table 2 (continued)

\begin{tabular}{|c|c|c|c|c|c|c|c|}
\hline Gene & Correlated organisms & $\mathrm{D}+\mathrm{C}$ & $\mathrm{S}+\mathrm{C}$ & CCnov & CCfeb & MF & Unamended \\
\hline \multirow[t]{3}{*}{ nos $Z$ clade II } & Adhaeribacter & $+*$ & & $+* * *$ & $+* * *$ & & \\
\hline & Flavobacterium & & & $+*$ & & & \\
\hline & Rhodothermaceae & $+^{*}$ & & $+* *$ & $+* * *$ & $+* *$ & $+* *$ \\
\hline
\end{tabular}

+ means positive correlation in comparison to initial soil;--means negative correlation in comparison to initial soil

* $q$ value $0.01<0.05 ; * * 0.001<0.01 ; * * * 0.001$

$D+C$ digestate + compost; $S+C$ sewage sludge + compost; CCnov $\mathrm{CC}$ residues from November; $C C f e b$ CC residues from February; $M F$ mineral fertilizer

Table 3 Correlation analyses of plant growth-promoting bacteria and fungi and the different treatments

\begin{tabular}{|c|c|c|c|c|c|c|c|}
\hline Gene & Correlated organisms & $\mathrm{D}+\mathrm{C}$ & $\mathrm{S}+\mathrm{C}$ & CCnov & CCfeb & MF & Control \\
\hline \multirow{19}{*}{$\begin{array}{l}\text { Plant growth- } \\
\text { promoting } \\
\text { Bacteria } \\
\text { (PGPB) }\end{array}$} & Acinetobacter & $-*$ & & $+*$ & & & $-*$ \\
\hline & Alcaligenes & & $+*$ & & & & \\
\hline & Arthrobacter & & & $+* * *$ & $+* * *$ & $+^{*}$ & \\
\hline & Azospirillum & & $+*$ & $+* *$ & $+* * *$ & & \\
\hline & Bacillus & & & & $+* *$ & & \\
\hline & Bradyrhizobium & & & & & $-*$ & \\
\hline & Caulobacter & & & $+* * *$ & $+* * *$ & & \\
\hline & Chryseobacterium & $-* * *$ & & & & $-*$ & $-* *$ \\
\hline & Flavobacterium & $-*$ & & & & $-*$ & $-*$ \\
\hline & Herbaspirillum & $+* * *$ & $+* * *$ & $+* *$ & $+*$ & $+* *$ & $+* * *$ \\
\hline & Kocuria & & & $+* * *$ & $+* * *$ & $+*$ & \\
\hline & Mesorhizobium & & $+*$ & $+* *$ & $+* *$ & & \\
\hline & Microbacterium & $-*$ & & & & & \\
\hline & Ochrobactrum & & $+* *$ & & & & \\
\hline & Paenibacillus & & & $+*$ & & & \\
\hline & Pseudomonas & $-* *$ & $-* *$ & & & $-*$ & $-* *$ \\
\hline & Rhodococcus & & & $+* *$ & & & $-*$ \\
\hline & Stenotrophomonas & & & $+*$ & & & $-*$ \\
\hline & Streptomyces & & $+*$ & & & & \\
\hline \multirow{5}{*}{$\begin{array}{l}\text { Plant growth- } \\
\text { promoting } \\
\text { Fungi } \\
\text { (PGPF) }\end{array}$} & Aspergillus & & $+* * *$ & & & & \\
\hline & Colletotrichum & $-* * *$ & $-* * *$ & $-* * *$ & $-* * *$ & $-* * *$ & $-* * *$ \\
\hline & Mortierella & & & & $+*$ & & \\
\hline & Penicillium & & & $-*$ & $-*$ & & \\
\hline & Talaromyces & & & $-* *$ & $-* *$ & & \\
\hline
\end{tabular}

+ means positive correlation in comparison to initial soil;- - means negative correlation in comparison to initial soil

${ }^{*} p$ value $0.01<0.05 ; * * 0.001<0.01 ; * * *<0.001$

$D+C$ digestate + compost; $S+C$ sewage sludge + compost; $C$ Cnov CC residues from November; $C C f e b$ CC residues from February; $M F$ mineral fertilizer samples. In a previous study (Brenzinger et al. 2018), compost reduced the GWP in unplanted agricultural soil. However, compost alone cannot be used as the sole fertilizer for agricultural purposes, because of the low $\mathrm{N}$ and $\mathrm{P}$ contents. Therefore, compost needs to be combined with other more nutrient-rich organic amendments, like digestate to combine soil structure and $\mathrm{C}$ improving traits of compost with the minerals for plant growth from digestate. This $\mathrm{D}+\mathrm{C}$ combination still had the lowest cumulative GHG emission in both tested soils, consistent with previous findings (Brenzinger et al. 2018); however, the cumulative GHG emission of the control treatment with MF was in the same order of magnitude as in the clay soil. While the $\mathrm{D}+\mathrm{C}$ treatment had the lowest $\mathrm{N}_{2} \mathrm{O}$ emissions, their contribution was mainly resulting from $\mathrm{CO}_{2}$ produced at the beginning of the incubation. On the other hand, the main contribution of MF to 


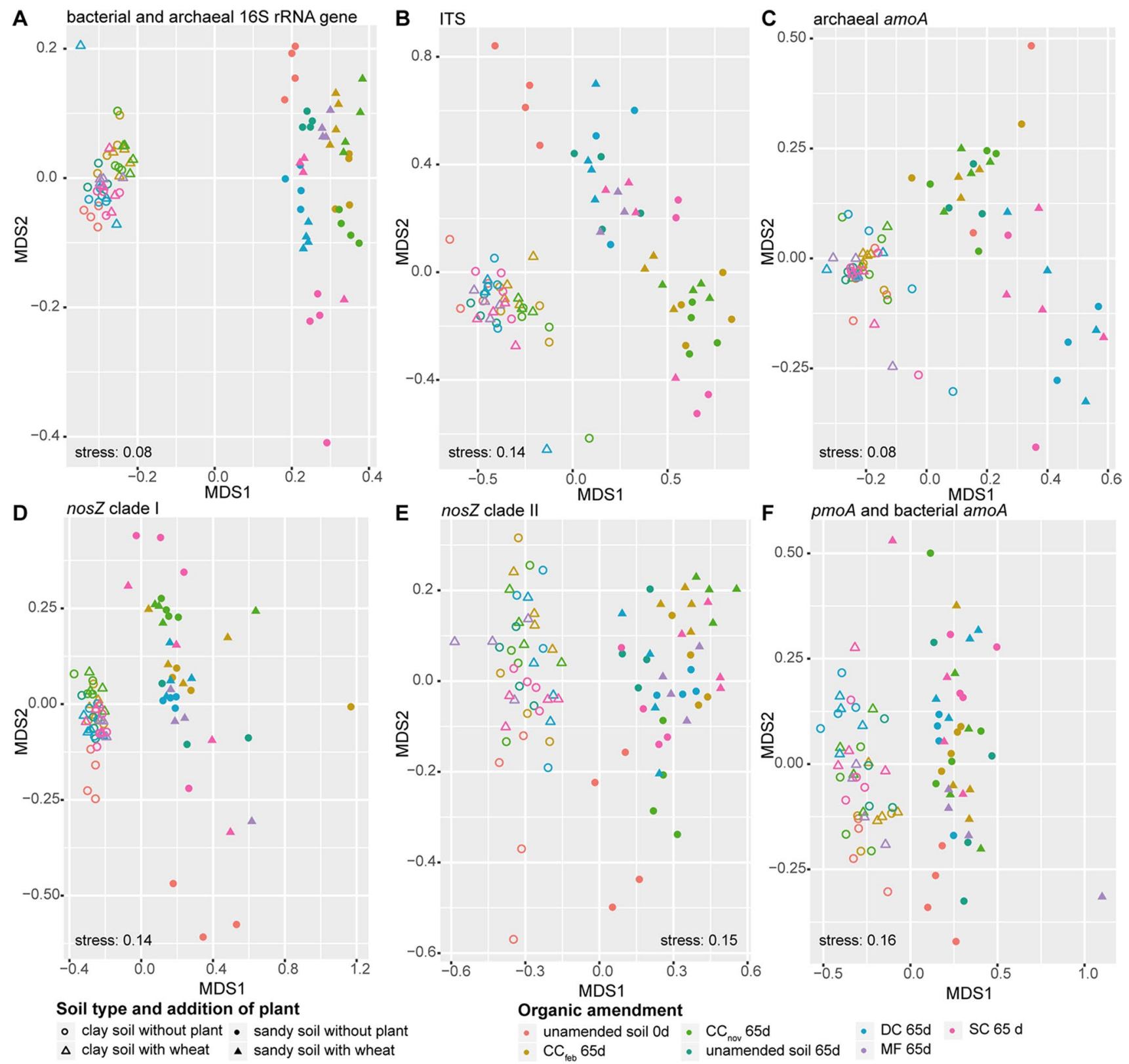

Fig. 5 Non-metric multidimensional scaling (NMDS) of Bray-Curtis distances from the bacterial 16S rRNA genes (A), ITS (B), archaeal amoA (C), nosZ clade I (D), nosZ clade II (E), and pmoA/ bacterial $a m o A(\mathbf{F})$ community composition in clay (open symbols) and sandy

the cumulative GHG consisted of $\mathrm{N}_{2} \mathrm{O}$ since MF does not introduce new $\mathrm{C}$ into the soil and it is not contributing to soil sustainability. The highest cumulative GHG emission was associated with $\mathrm{CC}$ residue addition. A reason was probably the more easily accessible $\mathrm{C}$ source for microorganisms in plant residue samples, which lead to a more rapid consumption of the freshly provided $\mathrm{C}$ substrate with an almost $10 \times$ higher $\mathrm{CO}_{2}$ respiration rate at the beginning of the experiment. This was also observed in other studies in which plant residue amendment immediately led to a high (closed symbols) soil derived from different applications of organic amendments, mineral fertilizers and un-amended soil (at 0 days and 65 days), with (triangle) and without (circle) plant growth

$\mathrm{CO}_{2}$ respiration rate (Ho et al. 2017; Brenzinger et al. 2018), which correlated with an increased enzyme activity of proteases, $\beta$-glucosidase, exocellulase, and $\beta$-glucosaminidase (Geisseler et al. 2011). Considering our study and previous work, the $\mathrm{C}: \mathrm{N}$ ratio does not reflect the soil responses (microbial $\mathrm{CO}_{2}$ production) to residue input. Although having similar $\mathrm{C}: \mathrm{N}$ ratios, different $\mathrm{CO}_{2}$ production rates were observed following the amendments.

One limitation of assessing the impact of different amendments on the agricultural GHGs is that it does not include 
metrics like long-term soil sustainability and the general C footprint before adding the amendments to the soil. Several studies calculated a life-cycle assessment for similar amendments and fertilizer that were used in this study based on their GWP (Table 4). Only CC residues showed a negative GWP before being applied in our study (Table 4), while the mineral fertilizer has the highest GWP before application. Additionally, $\mathrm{CC}$ residues can increase the $\mathrm{C}$ pool by $\mathrm{C}$ sequestration in the soil and take up available $\mathrm{N}$ from the soil (Lal 2015; Abdalla et al. 2019). Thus, residues like CC limits $\mathrm{N}$ leaching after fertilization; the sequestered $\mathrm{N}$ can then be used by the crops. The disadvantage of MF in this regard compared to the used organic amendments is the lack of contribution to the build-up of soil $\mathrm{C}$ and its unsustainable production process. The organic residues used are either sequester $\mathrm{C}$ while growing $(\mathrm{CC})$ or are a product of the waste treatment chain (compost, sewage sludge, digestate) and as such recycled. Therefore, other benefits of organic amendments besides GHG reduction have to be considered when selecting soil additives.

$\mathrm{N}_{2} \mathrm{O}$ production showed the largest difference between the two soil types and the different amendments. The increased $\mathrm{N}_{2} \mathrm{O}$ production in the sandy soil compared to the clay soil is likely stimulated by the acidity of the sandy soil. Low $\mathrm{pH}$ was previously shown to be a major driver in $\mathrm{N}_{2} \mathrm{O}$ emissions and $\mathrm{N}_{2} \mathrm{O}: \mathrm{N}_{2}$ ratios (Bakken et al. 2012; Brenzinger et al. 2015; Cheng et al. 2015; Aamer et al. 2020). Furthermore, the acidic $\mathrm{pH}$ appears to have a drastic impact on the $\mathrm{NO}_{3}{ }^{-}: \mathrm{NH}_{4}{ }^{+}$proportion, and with that on the nitrifier:denitrifier activity. In the clay soil, the production of $\mathrm{N}_{2} \mathrm{O}$ seems to be equally driven by nitrification and denitrification based on the simultaneous decrease of $\mathrm{NO}_{3}{ }^{-}$and $\mathrm{NH}_{4}{ }^{+}$concentrations in these samples in the first 21 days. In contrast, $\mathrm{NO}_{3}{ }^{-}$concentration gradually increased over time in the sandy soil, suggesting that in this soil, the majority of $\mathrm{N}_{2} \mathrm{O}$ production occurs during nitrification, which is also supported by strong positive correlation analyses of the AOB abundance to the $\mathrm{N}_{2} \mathrm{O}$ fluxes. $\mathrm{A}{ }^{15} \mathrm{~N}$-labelling experiment would be necessary to determine the actual contribution of the different pathways to the $\mathrm{N}_{2} \mathrm{O}$ production. However, the amount of $\mathrm{N}$ provided by the different fertilizers seems to be a good indicator for eventual $\mathrm{N}_{2} \mathrm{O}$ production, since our SEM analyses (Online Resource 13) showed a direct effect of added $\mathrm{N}$ on $\mathrm{N}_{2} \mathrm{O}$ production.

As mentioned before, $\mathrm{CH}_{4}$ uptake had a minor effect on the combined GHG emissions and showed no significant difference between treatments, which was also shown in our SEM analyses (Online Resource 13), in which none of the treatments showed an influence on the total mean $\mathrm{CH}_{4}$ concentrations during the whole incubation. Only the soil type seems to have a direct effect under some circumstances. Nevertheless, an increase in atmospheric $\mathrm{CH}_{4}$ uptake was documented towards the end of the incubation (Online Resource 5), especially in the amendments with compost in combination with other organic fertilizers (uptake rate of -0.35 to $0.59 \mu \mathrm{mol} \mathrm{m}{ }^{-2} \mathrm{~min}^{-1}$ in clay soil and -0.15 to $0.22 \mu \mathrm{mol} \mathrm{m}{ }^{-2} \mathrm{~min}^{-1}$ in the sandy soil), which was almost double than the control MF and unamended soil. This could indicate a long-term effect of compost on $\mathrm{CH}_{4}$ uptake. The increase in $\mathrm{CH}_{4}$ consumption was accompanied by the increase in the abundance of the $p m o A$ gene. Confirming a previous study of the same soil, the community was comprised of canonical aerobic methanotrophs (Methylocaldum and Methylocystis), not only thought to mediate 'low-affinity' $\mathrm{CH}_{4}$ oxidation but also capable of oxidizing $\mathrm{CH}_{4}$ at (circum-)atmospheric concentrations ( $\left.<40 \mathrm{ppmv}\right)$ (Ho et al. 2019). However, the application of organic fertilizers may stimulate $\mathrm{CH}_{4}$ production in anoxic microsites (Ho et al. 2015), sustaining the 'low-affinity' methanotrophs when oxygen is available. In the sandy soil, we observed an increase in smaller aggregates (Online Resource 8/9), especially in compost treatments with no plant present, which were also the samples that increased in $\mathrm{CH}_{4}$ uptake rates at the end of the incubation. Additionally, with regard to

Table 4 Life-cycle assessment of each amendment before the application on the field

\begin{tabular}{|c|c|c|}
\hline Amendment & $\begin{array}{l}\text { GWP before } \\
\text { application }\end{array}$ & References \\
\hline $\begin{array}{l}\text { Sewage sludge } \\
{\left[\mathrm{kg} \mathrm{CO}_{2} \text { eq. } / \mathrm{kg} \text { of sludge }\right]} \\
+ \text { Compost } \\
{\left[\mathrm{kg} \mathrm{CO}_{2} \text { eq. } / \mathrm{kg} \text { compost }\right](1: 3 \text { ratio })}\end{array}$ & $\sim 1.08$ & $\begin{array}{l}\text { Bridle and Skrypski-Mantele (2000); Murray et al. (2008); Hong et al. (2009); Martínez- } \\
\text { Blanco et al. (2009); Peters and Rowley (2009) }\end{array}$ \\
\hline $\begin{array}{l}\text { Digestate } \\
{\left[\mathrm{kg} \mathrm{CO}_{2} \text { eq. / kg digestate }\right]} \\
+ \text { Compost } \\
{\left[\mathrm{kg} \mathrm{CO}_{2} \text { eq. } / \mathrm{kg} \text { compost }\right](1: 3 \text { ratio })}\end{array}$ & $\sim 0.76$ & Martínez-Blanco et al. (2009); Rehl and Müller (2011); Styles et al. (2018) \\
\hline $\begin{array}{l}\text { Cover crop residue } \\
{\left[\mathrm{kg} \mathrm{CO}{ }_{2} \text { eq. / kg cover crop growth }\right]}\end{array}$ & $\sim-1.59$ & Tribouillois et al. (2018) \\
\hline $\begin{array}{l}\text { Mineral fertilizer } \\
{\left[\mathrm{kg} \mathrm{CO}_{2} \text { eq./ } \mathrm{kg} \text { mineral fertilizer }\right]}\end{array}$ & $\sim 2.92$ & $\begin{array}{l}\text { Martínez-Blanco et al. (2009); Skowronska and Filipek (2014); Hasler et al. (2015); } \\
\text { Brentrup et al. (2016) }\end{array}$ \\
\hline
\end{tabular}


the changes in aggregate sizes, our observations were corroborated by the detection of the methanogens in the same soil. Possibly, the methanotrophs were able to store sufficient reducing equivalents during high $\mathrm{CH}_{4}$ availability for atmospheric $\mathrm{CH}_{4}$ oxidation. Moreover, some methanotrophs (e.g., Methylocapsa) can gain energy from hydrogen and carbon monoxide to generate reducing equivalents (Pratscher et al. 2018; Tveit et al. 2019). Additionally, the availability of $\mathrm{NH}_{4}{ }^{+}$in our samples at the beginning of the incubation may transiently inhibit the $\mathrm{CH}_{4}$ oxidation capacity of the soil. Due to competition with nitrifiers, additional $\mathrm{NH}_{4}{ }^{+}$could lead to an inhibition of the $\mathrm{CH}_{4}$ monooxygenase (Malyan et al. 2016; Singh and Seneviratne 2017; Bodelier et al. 2019) and/or to a reduced $\mathrm{CH}_{4}$ production by methanogens (Yin et al. 2020).

\section{Effect of organic amendment on crop biomass and effect of crop growth on GHG fluxes}

Assessing the effect of crop growth on GHG fluxes our measured values need to be taken with cautions, since we only measured the GHG fluxes during light hours in our mesocosm experiment. Thereby, we underestimate especially the production of $\mathrm{CO}_{2}$ by plants during night times, leading to incomplete total cumulative GHG fluxes. Studies showed that the $\mathrm{CO}_{2}$ production during darkness can be 2-10x lower than the photosynthetic $\mathrm{CO}_{2}$ assimilation capacity of wheat (Gifford et al. 1985; Corey et al. 1997; Impa et al. 2019). Since there is not an exact number regarding the ratio between dark $\mathrm{CO}_{2}$ production and assimilation during photosynthesis, we cannot readjust our $\mathrm{CO}_{2}$ flux measurements and will consider our underestimate $\mathrm{CO}_{2}$ fluxes in the following. However, during the dark, also less $\mathrm{C}$ is secreted from the plant roots into the soil, which leads to a lower soil respiration rate during the night, which buffers the effect of the plant-produced $\mathrm{CO}_{2}$ in our mesocosms.

Crop growth may alter $\mathrm{GHG}$ emissions by direct fixing $\mathrm{CO}_{2}$ uptake and/or indirectly via competition for $\mathrm{N}$ with microorganisms. However, in our mesocosm experiment, this effect was not as strong as expected, even though we see a reduction of the cumulative GHG in all samples with crop growth compared to the samples without. This effect was more prominent in the sandy soil than in the clay soil. We expected $\mathrm{CO}_{2}$ uptake in microcosms with plants to be higher than in the unplanted systems, especially since the fluxes were only measured during daytime. However, this was not the case and both treatments took up $\mathrm{CO}_{2}$ at a later stage in our mesocosms. This was probably due to the growth of Cyanobacteria on the soil surface of the unplanted systems. Like plants, Cyanobacteria are also capable of $\mathrm{CO}_{2}$ fixation via the Calvin cycle (McFarlane et al. 2019). Surprisingly, we only observed a significant reduction of $\mathrm{N}_{2} \mathrm{O}$ emission in the sandy soil and not in the clay soil, suggesting lower $\mathrm{N}$ mineralization and subsequent nitrification in the sandy soil, leaving more $\mathrm{N}$ available for plants in an early growth phase. We observed the initial plant growth after 7 days in both soils; at this point, most $\mathrm{N}$ in the clay soil was already consumed by microorganisms and converted into $\mathrm{N}_{2} \mathrm{O}$. Additionally, the clay content could have decreased the production of ammonium from organic $\mathrm{N}$ in the clay mesocosms, which would also explain the increase of ammonium in the first days of the incubation in the sandy mesocosms (Online Resource 6).

Accounting for the crop performance, $\mathrm{CC}$ residue amendment induced a plant growth-promoting effect compared to MF. This was somehow surprising since we added more or less the same amount of $\mathrm{N}$ by the $\mathrm{CC}$ residues than we added with $\mathrm{MF}$ and $\mathrm{S}+\mathrm{C}$. One reason could be the easily accessible amount of $\mathrm{N}$ in the $\mathrm{CC}$ residues for the plant. However, this was also the case for the $\mathrm{S}+\mathrm{C}$ treatment. Hence, the nature of the $\mathrm{N}$ products added to the soil can be the major factor, which is more favourable for plant growth in CC residue. Another reason could be the stimulation of PGPB (Table 3 ) by the CC residues. Even though we did not measure the wheat yield, it is known that all measured parameters are highly correlated with the crop yield. Therefore, in this regard, an increase in crop performance by the $\mathrm{CC}$ residues addition will follow by an increase in crop yield.

Crop development was comparable between the two agricultural soils, except for the $\mathrm{D}+\mathrm{C}$ treatment in the sandy where crop growth was impaired. The reason for the lower growth remains to be determined. Nevertheless, it could be deduced that the crop was $\mathrm{N}$-limited, given that a complete uptake of $\mathrm{NO}_{3}{ }^{-}$and $\mathrm{NH}_{4}{ }^{+}$was detected already after 21 days in this treatment, whereas in the other treatments, $\mathrm{NO}_{3}{ }^{-}$was still available. Hence, $\mathrm{D}+\mathrm{C}$ may not be a suitable soil additive for plant growth, despite having the lowest cumulative GHG. Accounting for plant growth, cumulative GHG, and including the life cycle analysis, in our study, the $\mathrm{CC}$ residue amendment seems to be the best fertilizer and soil sustainable strategy in both soils. Maybe a proper combination of $\mathrm{CC}$ residue with green manure needs to be established as an agricultural management practice; however, the $\mathrm{N}$ added with the manure needs to be carefully evaluated. This is especially needed when the $\mathrm{CC}$ growth during the winter is negatively affected by weather extremes.

\section{How are microorganisms involved in GHG transformation and beneficial to plant growth affected by organic fertilizers}

\section{Changes in microbial community composition initiated by organic amendments}

The microbial community composition was strongly dependent on the soil type (Fig. 5), whereby edaphic characteristics 
( $\mathrm{pH}$, water holding capacity, metal composition) are the major drivers for differences in microbial communities and activities (Garbeva et al. 2004; Drenovsky et al. 2010; Ma et al. 2015; Kaupper et al. 2020b). However, within each soil type, the composition of the microbial community was affected by the different amendments, as revealed by the NMDS analysis. Residue application exerted a stronger impact on the bacterial community in the sandy than clay soil, in agreement with previous work (16S rRNA-gene based study) of the same soils (Ho et al. 2017). Extending on this study, we showed that this trend was also consistent across different microbial groups, including the archaea and fungal community, as well as other specific microbial guilds. The influence of the organic amendments on the community compositions is more pronounced than the changes after MF application or during incubation in the un-amended control soil. Additionally, our correlation analyses showed that organic amendments promoted microorganisms relevant for reducing GHG emissions, including the nos $Z$ clade I (e.g. Rhizobiales, Rhizobium), nosZ clade II (Adhaeribacter), or methanotrophs (Methylocaldum-like). An increase in the relative abundance of $\mathrm{N}_{2} \mathrm{O}$-reducers mainly correlated with $\mathrm{CC}$ residue while the stimulation of the methanotrophic community was mostly found in compost amended samples. The positive correlation of more $\mathrm{N}_{2} \mathrm{O}$-reducers with the $\mathrm{CC}$ residue treatment could be explained by the higher production of $\mathrm{N}_{2} \mathrm{O}$ occurring in the $\mathrm{CC}$ residue samples. Thereby, $\mathrm{N}_{2} \mathrm{O}$-reducers have a longer period to use $\mathrm{N}_{2} \mathrm{O}$ as an electron acceptor to gain energy for growth, while the $\mathrm{CC}$ residue samples also provide a $\mathrm{C}$ source as an electron donor (Hallin et al. 2018). We did not observe any negative correlation (decrease in relative abundance) of any genera that are important for reducing GHG emissions with any of the organic amendments nor in the MF control compared to the starting material. However, we observe negative correlations for the bacterial and archaeal nitrifier community with the organic amendments, which is a beneficial effect, as the microorganisms involved in $\mathrm{N}_{2} \mathrm{O}$ production were adversely affected. Accordingly, Nitrospira species (Van Kessel et al. 2015) also decreased in all samples except for the D+C sample. Since the so-called comammox Nitrospira species are not known to emit $\mathrm{N}_{2} \mathrm{O}$, this is potentially a beneficial effect of the $\mathrm{D}+\mathrm{C}$ amendment. Taken the total composition and the correlation analyses together, the microbial community composition shifted, favouring microorganisms involved in the reduction of GHG emissions after the application of organic fertilizers as compared to mineral fertilizer.

\section{Changes in microbial abundance initiated by organic amendments}

Besides the relative composition of microbial communities, a potential indicator for 'a climate smarter' agricultural soil is the total abundance of GHG-reducing microorganisms. Both nosZ-groups and the methanotrophs showed an increase in absolute abundance after organic residue amendment compared to MF and un-amended soil. This trend was stronger in the sandy soil than in the clay soil. In addition, a spike in the abundance of diazotrophs was detected after the application of different organic amendments, which could be an additional positive feature for agricultural soils as they are important for plant growth. In the clay soil, taking all positive effects on GHG reductions and promoting plant growth together, the $\mathrm{CC}_{\text {nov }}$ residues showed the highest impact on the microbial abundance (average of +19 times increase against the initial soil), while in the sandy soil the effects were not as strong. Here, $\mathrm{D}+\mathrm{C}$ and $\mathrm{S}+\mathrm{C}+\mathrm{P}$ treatment showed the best overall performance with an enhancement of 1.35 and 2.52 , respectively. Like in the microbial community composition, the soil type has a stronger influence on the total microbial abundance. For example, the archaeal nitrifier community showed an increase in the clay soil over time, while they decreased in the sandy soil. In both soils, the organic amendments lowered the abundance of archaeal nitrifiers in comparison to the un-amended soil and the MF treatment. Other studies found similar effects, in which organic amendment reduced AOAs in comparison to AOBs, since AOAs are known to be more dominant in $\mathrm{NH}_{4}{ }^{+}$poor environments, with low $\mathrm{NH}_{4}{ }^{+}$concentration; in agricultural soils, a continuous addition of $\mathrm{NH}_{4}{ }^{+}$is provided (Huang et al. 2004; Gubry-Rangin et al. 2010; Scarlett et al. 2021). Additionally, the lower numbers of AOA in the sandy soil may be explained by the lower $\mathrm{pH}$ as was demonstrated in other studies (Schleper and Nicol 2010). However, in more recent publications, it was demonstrated that $\mathrm{AOA}$ seems to be unaffected by $\mathrm{pH}$ and that $\mathrm{AOB}$ is decreasing with lower pH (Yao et al. 2011; Scarlett et al. 2021). It seems more likely that the $\mathrm{NH}_{4}{ }^{+}$concentrations that remained at a higher level for a longer period in the sandy soil are responsible for the observed differences in AOA and AOB abundance. Our findings indicate the interplay of biotic and abiotic factors driving GHG turnover processes in agricultural soils. Therefore, in future studies aiming at reducing GHG emissions from agricultural soils, it is of particular importance to monitor the changes in the soil microbiome.

\section{Changes in composition of plant growth-promoting bacteria and fungi initiated by organic amendments}

The $\mathrm{CC}$ residue and $\mathrm{S}+\mathrm{C}$ amendments have a pronounced positive effect on the relative abundance of the PGPB community (e.g. increase of Arthrobacter, Azospirillum, Bacillus, Herbaspirillum, and Mesorhizobium), while three other treatments showed a negative effect on the overall PGPB relative abundance (e.g. decrease of Acinetobacter, Chryseobacterium, Flavobacterium, and Pseudomonas) (Table 3). 
Azospirillum, Bacillus, and Rhizobia species are the best studied PGPB. These microorganisms have been associated to play a role in root development (Remans et al. 2008; Cassán et al. 2020), enhanced plant nutrient uptake (Adesemoye et al. 2008; Safronova et al. 2012; Egamberdieva et al. 2017; Kim et al. 2017), phosphate solubilisation and overall improvement of different crop species (Arif et al. 2017; Khan et al. 2017; Cassán et al. 2020), bioremediation of heavy metals from contaminated soils (Gururani et al. 2013), induced tolerance to drought (Gururani et al. 2013; García et al. 2017), and inhibition of bacterial and fungal pathogens (Liu et al. 2018), among other benefits for plant growth. Thus, the increased plant growth could be linked to higher PGPB abundance in the CC residue-amended soils (Fig. 2). This finding seems to be another beneficial effect of the amendment of organic fertilizers (except the D+C treatment) in comparison to MF. While we observe a strong effect of the organic amendments on the PGPB, the PGPF was not or only marginally affected by the different treatments. Not only were the beneficial PGPF less affected, but organic fertilizer amendments also had little effect on the pathogenic fungi. The reason could be that our organic amendments harboured higher bacterial than fungal abundances and the microbial community composition was more strongly influenced by the residue-borne microorganisms than stimulation of the indigenous soil community.

\section{What are the potential sources of the beneficial microorganisms?}

Our results suggest that both the indigenous soil microorganisms and those derived from the organic fertilizers are relevant for reducing GHG emissions and promoting crop growth. MF application cannot provide new microorganisms in the mesocosms since the MF is chemically produced and not a habitat for microorganisms itself. However, we still observe changes in the microbial composition and abundance in the MF samples, which can then only be caused by the addition of newly added substrates. These changes are more pronounced with the organic amendment application, and strikingly, many genera that emerged during the incubation were not detected in the initial soil. For example, the methanotrophs and methanogens which were not detected in the initial soil in the MF $+\mathrm{P}$ or un-amended soil samples increased in abundance over time particularly in the amendments with compost. Additionally, we also observe these changes with the $\mathrm{N}_{2} \mathrm{O}$-reducers which show a clear correlation with especially the $\mathrm{CC}$ residue samples, which did not occur in the unamended soil and the MF treatment. These observations strongly suggest the persistence of the microorganisms introduced via the organic amendments, which can be regarded as a legacy of the amendments, contributing to a reduced GHG emission, increased plant growth, and overall soil health.

Amending bacterial strains to improve soil quality and promote plant growth is a relatively new field, which can provide extensive application possibilities (Dini-Andreote and Raaijmakers 2018). For instance, inoculation of Dyadobacter fermentans - a non-denitrifying bacterium possessing only clade II nos $Z$ and to different soils resulted in a decrease in $\mathrm{N}_{2} \mathrm{O}$ emission of up to $189 \%$ in one-third of the inoculated soils (Domeignoz-Horta et al. 2016). However, two-thirds of the soils were not affected by the addition, even though the results suggested that the added $D$. fermentans was capable to survive in the soil and that the effects were hampered in soils with lower $\mathrm{pH}$ or $\mathrm{C} / \mathrm{N}$ ratio. Additionally, a recent review highlights the need of establishing a beneficial home for plant growth-promoting bacteria by e.g. design crops with extended root phenotypes and genotypes or develop new strategies to engineer crops (Song et al. 2021). Potentially organic fertilizers, especially plant-based ones, can help to establish these beneficial homes.

\section{Conclusion}

We screened different organic amendments as a single application or in combination to observe their influence on their GHG emissions as well as on plant yield in a mesocosm experiment with two agricultural soils. Additionally, we determined the changes occurring in microorganisms through the application of organic amendments. Confirming previous work, we showed the potential to reduce GHG emissions from agricultural soils by the application of organic amendments (Ho et al. 2015; Brenzinger et al. 2018); however, also the addition of MF in our mesocosm led to a promising development of the cumulative GHG. Extending current understanding, we show that organic amendments can, on the one hand, promote plant growth in comparison to MF at least with the plant residue samples and that we can alter and enrich the microbial community by organic amendments which, on the other hand, can promote soil quality and GHG reduction. This alteration of the microbial community could be the legacy effect towards climatesmart agriculture by organic amendments in comparison to mineral fertilizers. However, there are still some open questions about the application of organic amendments that we cannot fully answer in our experiment. To what extent do the organic amendments influence the soil organic $\mathrm{C}$ in that regard our experiment is too short. Integrating all measured abiotic and biotic variables, the SEM analysis, and including the life cycle analyses, we suggest using CC residues as an organic amendment. Even though it showed the highest cumulative GHG in our experiment, it had the best life cycle assessment, provided the best plant growth in both soils, and 
showed a good stimulation of PGPB and microbes that could reduce GHG from soils in the future (Fig. 6), but this needs to be evaluated in a field study under natural conditions. Understanding the underlying mechanisms of how organic fertilizers can make agricultural soils 'climate smarter' could contribute to mitigating climate change.

Supplementary Information The online version contains supplementary material available at https://doi.org/10.1007/s00374-021-01599-5.

Acknowledgements We thank Dr. Susanne Brenzinger for helping with the creation of Fig. 6. We are grateful to Iris Chardon, Agata Pijl, and Hans Zweers for their excellent technical assistance. We thank Jeroen van Lanen (Van Iersel Compost, The Netherlands) for providing us with the compost, Phillipe Packbier (Joordens company, The Netherlands) for providing us with the CC residues, Rob Verheijn (Vallei Veluwe, The Netherlands) for providing us with the sewage sludge, and Rommie van der Weide and Sjaak van Brugge (ACRRES, The Netherlands) for providing us with digestate. Thankfully, Dr. Emilia Hannula provided us a database of fungal pathogens. Sander van Acqouij and Anna-Reetta Salonen for experimental help with wet sieving to determine aggregate fractions. We thank Prof. Dr. Rob van Spanning for fruitful discussion about our data. This publication is publication number 7285 of the Netherlands Institute of Ecology (NIOO-KNAW).

Author Contribution KB, AH, and PLEB conceived the study. KB performed all mesocosm experiments. KB carried out laboratory work with the help from GK who performed the aggregate measurements. OYAC performed the sequence analyses, while DW and KB did the statistical analyses of the data. BR and KB did the SEM analyses. GK organised all organic amendments. KB wrote the paper with the help from all co-authors. All authors read and approved the final manuscript.

Funding $\mathrm{KB}$ is financially supported by the grant from the German DFG BR 5535/1-1 and by a grant from the Dutch Research Council (NOW) number 870.15.073.

Availability of data and materials The dataset supporting the conclusions of this article is available in the Dryad server repository, https://doi.org/10.5061/dryad.4qrfj6q9n. The raw sequences can be found at the European Nucleotide Archive under the accession number PRJEB43590 (http://www.ebi.ac.uk/ena/data/view/PRJEB43590; available at 31.12.2021).
Fig. 6 Overview of all measured results and ranked for each individual treatment, with a final score taking into account global warming potential (GWP) previous to application, cumulative $\mathrm{GHG}$ (derived from $\mathrm{CH}_{4}, \mathrm{CO}_{2}$, and $\mathrm{N}_{2} \mathrm{O}$ fluxes) during the mesocosm experiment, plant growth, enrichment of plant growth-promoting bacteria and plant growth-fungi (PGPB/PGPF), and GHG reducing microbes. $\mathrm{CC}$, cover crop residues; $\mathrm{D}+\mathrm{C}$, digestate + compost; $\mathrm{S}+\mathrm{C}$, sewage sludge + compost; MF, mineral fertilizer

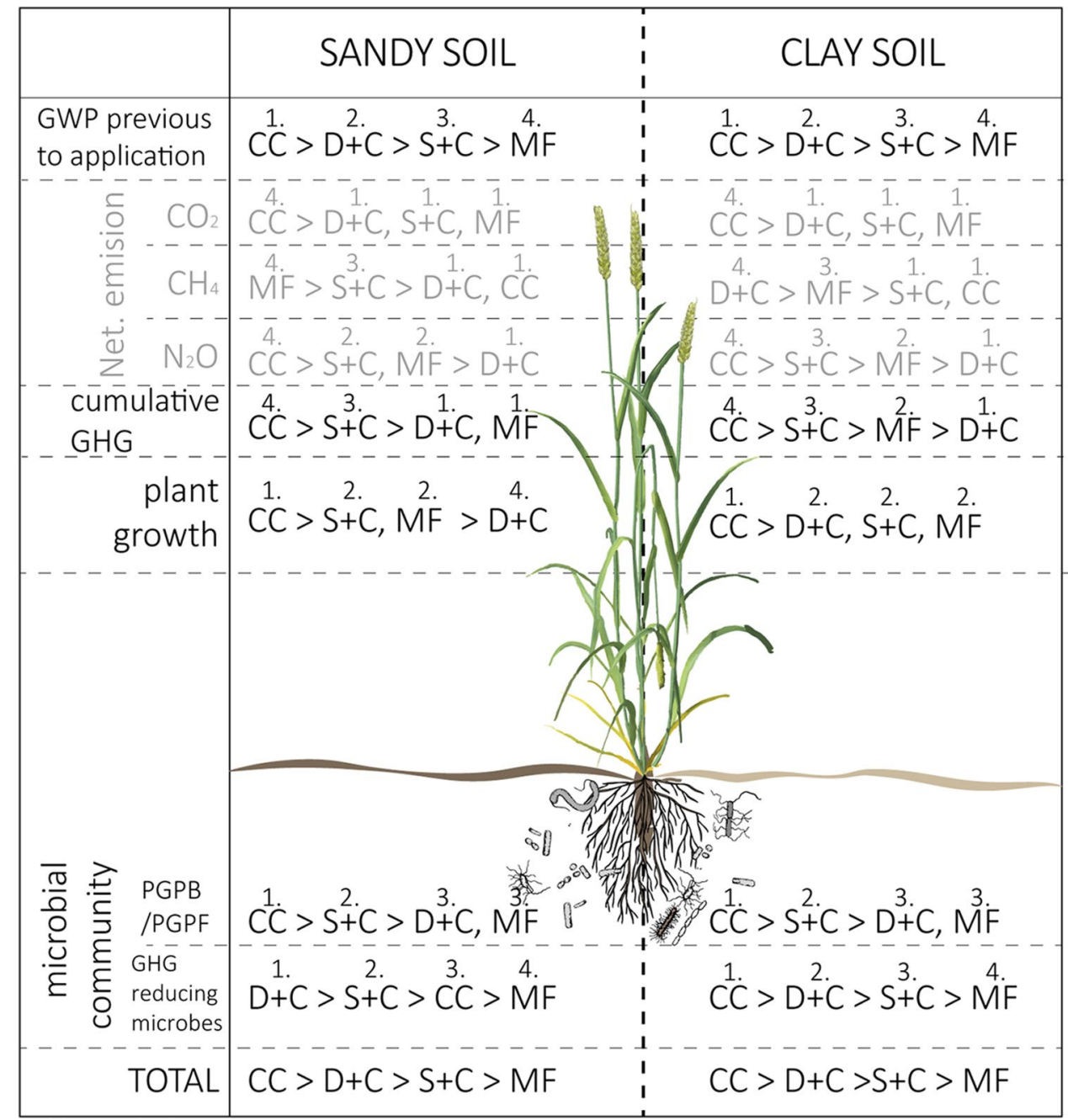


Code availability Scripts and code used to process functional gene OTUs will be published soon (Cost et al., in preparation).

\section{Declarations}

Conflict of interest Not applicable.

Open Access This article is licensed under a Creative Commons Attribution 4.0 International License, which permits use, sharing, adaptation, distribution and reproduction in any medium or format, as long as you give appropriate credit to the original author(s) and the source, provide a link to the Creative Commons licence, and indicate if changes were made. The images or other third party material in this article are included in the article's Creative Commons licence, unless indicated otherwise in a credit line to the material. If material is not included in the article's Creative Commons licence and your intended use is not permitted by statutory regulation or exceeds the permitted use, you will need to obtain permission directly from the copyright holder. To view a copy of this licence, visit http://creativecommons.org/licenses/by/4.0/.

\section{References}

Aamer M, Shaaban M, Hassan MU, Guoqin H, Ying L, Hai Ying T, Rasul F, Qiaoying M, Zhuanling L, Rasheed A, Peng Z (2020) Biochar mitigates the $\mathrm{N} 2 \mathrm{O}$ emissions from acidic soil by increasing the nos $\mathrm{Z}$ and nirK gene abundance and soil $\mathrm{pH}$. J Environ Manage 255:109891. https://doi.org/10.1016/j.jenvman.2019. 109891

Abdalla M, Hastings A, Cheng K, Yue Q, Chadwick D, Espenberg M, Truu J, Rees RM, Smith P (2019) A critical review of the impacts of cover crops on nitrogen leaching, net greenhouse gas balance and crop productivity. Glob Chang Biol 25:2530-2543. https:// doi.org/10.1111/gcb.14644

Adesemoye AO, Torbert HA, Kloepper JW (2008) Enhanced plant nutrient use efficiency with PGPR and AMF in an integrated nutrient management system. Can J Microbiol 54:876-886. https://doi. org/10.1139/W08-081

Arif MS, Shahzad SM, Yasmeen T, Riaz M, Ashraf M, Ashraf MA, Mubarik MS, Kausar R (2017) Improving plant phosphorus (p) acquisition by phosphate-solubilizing bacteria. In: Naeem M, Ansari A, Gill S (Eds) Essential Plant Nutrients: uptake, use efficiency, and management. Springer International Publishing, Cham, pp 513-556

Bakken LR, Bergaust L, Liu B, Frostegård A (2012) Regulation of denitrification at the cellular level: a clue to the understanding of N2O emissions from soils. Philos Trans R Soc B Biol Sci 367:1226-1234. https://doi.org/10.1098/rstb.2011.0321

Bodelier PLE, Steenbergh AK (2014) Interactions between methane and the nitrogen cycle in light of climate change. Curr Opin Environ Sustain 9-10:26-36

Bodelier PLE, Pérez G, Veraart AJ, Krause SMB (2019) Methanotroph ecology, environmental distribution and functioning. Springer, Cham, pp 1-38

Brenzinger K, Dörsch P, Braker G (2015) pH-driven shifts in overall and transcriptionally active denitrifiers control gaseous product stoichiometry in growth experiments with extracted bacteria from soil. Front Microbiol 6:961. https://doi.org/10.3389/fmicb.2015. 00961

Brenzinger K, Drost SM, Korthals G, Bodelier PLE (2018) Organic residue amendments to modulate greenhouse gas emissions from agricultural soils. Front Microbiol 9:1-16. https://doi.org/10.3389/ fmicb.2018.03035
Butterbach-Bahl K, Baggs EM, Dannenmann M, Kiese R, ZechmeisterBoltenstern S (2013) Nitrous oxide emissions from soils: how well do we understand the processes and their controls? Philos Trans. R. Soc. B Biol. Sci. 368:201

Cassán F, Coniglio A, López G, Molina R, Nievas S, de Carlan CLN, Donadio F, Torres D, Rosas S, Pedrosa FO, de Souza E, Zorita MD, de-Bashan L, Mora V, (2020) Everything you must know about Azospirillum and its impact on agriculture and beyond. Biol Fertil Soils 56:461-479. https://doi.org/10.1007/ s00374-020-01463-y

Chapuis-Lardy L, Wrage N, Metay A, Chotte JL, Bernoux M (2007) Soils, a sink for N2O? A review. Glob Chang Biol 13:1-17

Cheng Y, Zhang JB, Wang J, Cai ZC, Wang SQ (2015) Soil pH is a good predictor of the dominating $\mathrm{N} 2 \mathrm{O}$ production processes under aerobic conditions. J Plant Nutr Soil Sci 178:370-373. https://doi.org/10.1002/jpln.201400577

Ciais P, Sabine C, Bala G, Bopp L, Brovkin V, Canadell A, Chhabra R, DeFries R, Galloway J, Heimann C, Jones C, Le Quéré C, Myneni RB, Piao S, Thornton P (2009) Carbon and other biogeochemical cycles BT - climate change the physical science basis. Contribution of Working Group I to the Fifth Assessment Report of the intergovernmental Panel on Climate Change. In: Stocker TF, Qin D, Plattner G-K, Tignor M, Allen SK, Boschung J, Nauels A, Xia Y, Bex V, Midgley PM (Eds) Climate Change The physical Science Basis. Contribution of Working Group I to the Fifth Assessment Report of the intergovernmental Panel on Climate Change. Cambridge University Press, Cambridge, United Kingdom and New York, pp 465-570

Corey KA, Barta DJ, Henninger DL (1997) Photosynthesis and respiration of a wheat stand at reduced atmospheric pressure and reduced oxygen. Adv Sp Res 20:1869-1877. https://doi.org/10. 1016/S0273-1177(97)00854-5

Diacono M, Montemurro F (2010) Long-term effects of organic amendments on soil fertility. A Review Agron Sustain Dev 30:401-422

Dini-Andreote F, Raaijmakers JM (2018) Embracing community ecology in plant microbiome research. Trends Plant Sci 23:467-469

Domeignoz-Horta LA, Spor A, Bru D, Breuil MC, Bizouard F, Léonard J, Philippot L (2015) The diversity of the N2O reducers matters for the N2O:N2 denitrification end-product ratio across an annual and a perennial cropping system. Front Microbiol 6:971. https://doi.org/10.3389/fmicb.2015.00971

Domeignoz-Horta LA, Putz M, Spor A, Bru D, Breuil MC, Hallin S, Philippot L (2016) Non-denitrifying nitrous oxide-reducing bacteria - an effective N2O sink in soil. Soil Biol Biochem 103:376379. https://doi.org/10.1016/j.soilbio.2016.09.010

Doni F, Mispan MS, Suhaimi NSM, Ishak N, Uphoff N (2019) Roles of microbes in supporting sustainable rice production using the system of rice intensification. Appl Microbiol Biotechnol 103:51315142. https://doi.org/10.1007/s00253-019-09879-9

Drenovsky RE, Steenwerth KL, Jackson LE, Scow KM (2010) Land use and climatic factors structure regional patterns in soil microbial communities. Glob Ecol Biogeogr 19:27-39. https://doi.org/ 10.1111/j.1466-8238.2009.00486.x

Egamberdieva D, Davranov K, Wirth S, Hashem A, Abd-Allah EF (2017) Impact of soil salinity on the plant-growth - promoting and biological control abilities of root associated bacteria. Saudi J Biol Sci 24:1601-1608. https://doi.org/10.1016/j.sjbs.2017.07.004

Garbeva P, Van Veen JA, Van Elsas JD (2004) Microbial diversity in soil: selection of microbial populations by plant and soil type and implications for disease suppressiveness. Annu Rev Phytopathol 42:243-270

García JE, Maroniche G, Creus C, Suárez-Rodríguez R, RamirezTrujillo JA, Groppa MD (2017) In vitro PGPR properties and osmotic tolerance of different Azospirillum native strains and their 
effects on growth of maize under drought stress. Microbiol Res 202:21-29. https://doi.org/10.1016/j.micres.2017.04.007

Geisseler D, Horwath WR, Scow KM (2011) Soil moisture and plant residue addition interact in their effect on extracellular enzyme activity. Pedobiologia (jena) 54:71-78. https://doi.org/10.1016/j. pedobi.2010.10.001

Gifford RM, Lambers H, Morison JIL (1985) Respiration of crop species under CO2 enrichment. Physiol Plant 63:351-356. https:// doi.org/10.1111/j.1399-3054.1985.tb02309.x

Grace JB (2006) Structural equation modeling and natural systems. Cambridge University Press

Gubry-Rangin C, Nicol GW, Prosser JI (2010) Archaea rather than bacteria control nitrification in two agricultural acidic soils. FEMS Microbiol Ecol 74:566-574. https://doi.org/10.1111/j.1574-6941. 2010.00971.x

Gulledge J, Doyle AP, Schimel JP (1997) Different NH4+-inhibition patterns of soil $\mathrm{CH} 4$ consumption: a result of distinct $\mathrm{CH} 4-$ oxidizer populations across sites? Soil Biol Biochem 29:13-21. https://doi.org/10.1016/S0038-0717(96)00265-9

Gururani MA, Upadhyaya CP, Baskar V, Venkatesh J, Nookaraju A, Park SW (2013) Plant growth-promoting rhizobacteria enhance abiotic stress tolerance in solanum tuberosum through inducing changes in the expression of ROS-scavenging enzymes and improved photosynthetic performance. J Plant Growth Regul 32:245-258. https://doi.org/10.1007/s00344-012-9292-6

Hallin S, Philippot L, Löffler FE, Sanford RA, Jones CM (2018) Genomics and ecology of novel N2O-reducing microorganisms. Trends Microbiol 26:43-55. https://doi.org/10.1016/j.tim.2017. 07.003

Hannula SE, Morriën E, De Hollander M, Van Der Putten WH, Van Veen JA, De Boer W (2017) Shifts in rhizosphere fungal community during secondary succession following abandonment from agriculture. ISME J 11:2294-2304. https://doi.org/10.1038/ismej. 2017.90

Higgins SA, Schadt CW, Matheny PB, Löffler FE (2018) Phylogenomics reveal the dynamic evolution of fungal nitric oxide reductases and their relationship to secondary metabolism. Genome Biol Evol 10:2474-2489. https://doi.org/10.1093/gbe/evy187

Ho A, Reim A, Kim SY, Meima-Franke M, Termorshuizen A, de Boer W, van der Putten WH, Bodelier PLE (2015) Unexpected stimulation of soil methane uptake as emergent property of agricultural soils following bio-based residue application. Glob Chang Biol 21:3864-3879. https://doi.org/10.1111/gcb.12974

Ho A, Ijaz UZ, Janssens TKS, Ruijs R, Kim SY, de Boer W, Termorshuizen A, van der Putten WH, Bodelier PLE (2017) Effects of bio-based residue amendments on greenhouse gas emission from agricultural soil are stronger than effects of soil type with different microbial community composition. GCB Bioenergy 9:1707-1720. https://doi.org/10.1111/gcbb.12457

Ho A, Lee HJ, Reumer M, Meima-Franke M, Raaijmakers C, Zweers H, de Boer W, Van der Putten WH, Bodelier PLE (2019) Unexpected role of canonical aerobic methanotrophs in upland agricultural soils. Soil Biol Biochem 131:1-8. https://doi.org/10.1016/j. soilbio.2018.12.020

Hoffland E, Kuyper TW, Comans RNJ, Creamer RE (2020) Eco-functionality of organic matter in soils. Plant Soil 455:1-22. https:// doi.org/10.1007/s11104-020-04651-9

Hossain MM, Sultana F, Islam S (2017) Plant growth-promoting fungi (PGPF): phytostimulation and induced systemic resistance. In: Singh DP, Singh HB, Prabha R (Eds) Plant-Microbe Interactions in Agro-Ecological Perspectives. Springer Singapore, Singapore, pp 135-191

Huang Y, Zou J, Zheng X, Wang Y, Xu X (2004) Nitrous oxide emissions as influenced by amendment of plant residues with different C: N ratios. Soil Biol Biochem 36:973-981. https://doi.org/10. 1016/j.soilbio.2004.02.009
Hütsch BW (1998) Methane oxidation in arable soil as inhibited by ammonium, nitrite, and organic manure with respect to soil $\mathrm{pH}$. Biol Fertil Soils 28:27-35. https://doi.org/10.1007/s003740050 459

Impa SM, Sunoj VSJ, Krassovskaya I, Bheemanahalli R, Obata T, Jagadish SVK (2019) Carbon balance and source-sink metabolic changes in winter wheat exposed to high night-time temperature. Plant Cell Environ 42:1233-1246. https://doi.org/10.1111/pce. 13488

IPCC (2018) Global warming of $1.5^{\circ} \mathrm{C}$ - an IPCC special report on the impacts of global warming of $1.5^{\circ} \mathrm{C}$ above pre-industrial levels and related global greenhouse gas emission pathways. In: Masson-Delmotte V, Zhai P, Pörtner H-O, Roberts D, Skea J, Shukla PR, Piran A, Moufouma-Okia W, Péan C, Pidcock R, Connors S, Matthews JBR, Chen Y, Zhou X, Gomis MI, Lonnoy E, Maycock T, Tignor M, Waterfield T (Eds) Ipcc - Sr15. Intergovernmental Panel on Climate Change, Geneva, pp 17-20

Jones CM, Spor A, Brennan FP, Breuil MC, Bru D, Lemanceau P, Griffiths B, Hallin S, Philippot L (2014) Recently identified microbial guild mediates soil N2O sink capacity. Nat Clim Chang 4:801-805. https://doi.org/10.1038/nclimate2301

Kaupper T, Hetz S, Kolb S, Yoon S, Horn MA, Ho A (2020a) Deforestation for oil palm: impact on microbially mediated methane and nitrous oxide emissions, and soil bacterial communities. Biol Fertil Soils 56:287-298

Kaupper T, Luehrs J, Lee HJ, Mo Y, Jia Z, Horn MA, Ho A (2020b) Disentangling abiotic and biotic controls of aerobic methane oxidation during re-colonization. Soil Biol Biochem 142:107729. https://doi.org/10.1016/j.soilbio.2020.107729

Keuschnig C, Gorfer M, Li G, Mania D, Frostegård Å, Bakken L, Larose C (2020) NO and N2O transformations of diverse fungi in hypoxia: evidence for anaerobic respiration only in Fusarium strains. Environ Microbiol 22:2182-2195. https://doi.org/10. 1111/1462-2920.14980

Khan MMA, Haque E, Paul NC, Khaleque MA, Al-Garni SMS, Rahman M, Islam MT (2017) Enhancement of growth and grain yield of rice in nutrient deficient soils by rice probiotic bacteria. Rice Sci 24:264-273. https://doi.org/10.1016/j.rsci.2017.02.002

Kim MJ, Radhakrishnan R, Kang SM, You YH, Jeong EJ, Kim JG, Lee IJ (2017) Plant growth promoting effect of Bacillus amyloliquefaciens H-2-5 on crop plants and influence on physiological changes in soybean under soil salinity. Physiol Mol Biol Plants 23:571-580. https://doi.org/10.1007/s12298-017-0449-4

Lal R (2015) Cover cropping and the " 4 per thousand" proposal. J Soil Water Conserv 70:141A. https://doi.org/10.2489/jswc. 70.6.141A

Levine JG, Wolff EW, Jones AE, Sime LC, Valdes PJ, Archibald AT, Carver GD, Warwick NJ, Pyle JA (2011) Reconciling the changes in atmospheric methane sources and sinks between the Last Glacial Maximum and the pre-industrial era. Geophys Res Lett 38:L23804. https://doi.org/10.1029/2011GL049545

Liu K, McInroy JA, Hu CH, Kloepper JW (2018) Mixtures of plantgrowth-promoting rhizobacteria enhance biological control of multiple plant diseases and plant-growth promotion in the presence of pathogens. Plant Dis 102:67-72. https://doi.org/10.1094/ PDIS-04-17-0478-RE

Lucy M, Reed E, Glick BR (2004) Applications of free living plant growth-promoting rhizobacteria. Antonie van Leeuwenhoek. Int J Gen Mol Microbiol 86:1-25

Ma L, Guo C, Lü X, Yuan S, Wang R (2015) Soil moisture and land use are major determinants of soil microbial community composition and biomass at a regional scale in northeastern China. Biogeosciences 12:2585-2596. https://doi.org/10.5194/bg-12-2585-2015

Majeed A, Muhammad Z, Ahmad H (2018) Plant growth promoting bacteria: role in soil improvement, abiotic and biotic stress 
management of crops. Plant Cell Rep 37:1599-1609. https://doi. org/10.1007/s00299-018-2341-2

Malyan SK, Bhatia A, Kumar A, Gupta DK, Singh R, Kumar SS, Tomer R, Kumar O, Jain N (2016) Methane production, oxidation and mitigation: a mechanistic understanding and comprehensive evaluation of influencing factors. Sci Total Environ 572:874-896. https://doi.org/10.1016/j.scitotenv.2016.07.182

Maxfield PJ, Hornibrook ERC, Evershed RP (2008) Acute impact of agriculture on high-affinity methanotrophic bacterial populations. Environ Microbiol 10:1917-1924. https://doi.org/10.1111/j.14622920.2008.01587.x

McFarlane CR, Shah NR, Kabasakal BV, Echeverria B, Cotton CAR, Bubeck D, Murray JW (2019) Structural basis of light-induced redox regulation in the Calvin-Benson cycle in cyanobacteria. Proc Natl Acad Sci U S A 116:20984-20990. https://doi.org/10. 1073/pnas. 1906722116

McMurdie PJ, Holmes S (2013) Phyloseq: an R package for reproducible interactive analysis and graphics of microbiome census data. PLoS ONE 8:e61217. https://doi.org/10.1371/journal.pone. 0061217

Mosier AR, Delgado JA (1997) Methane and nitrous oxide fluxes in grasslands in western Puerto Rico. Chemosphere 35:2059-2082. https://doi.org/10.1016/S0045-6535(97)00231-2

Oksanen J, Blanchet FG, Friendly M, Kindt R, Legendre P, Mcglinn D, Minchin PR, O'hara RB, Simpson GL, Solymos P, Henry M, Stevens H, Szoecs E, Maintainer HW (2020) Package "vegan" Title Community Ecology Package Version 2.5-7

Paustian K, Lehmann J, Ogle S, Reay D, Robertson GP, Smith P (2016) Climate-smart soils. Nature. https://doi.org/10.1038/nature17174

Pratscher J, Vollmers J, Wiegand S, Dumont MG, Kaster AK (2018) Unravelling the identity, metabolic potential and global biogeography of the atmospheric methane-oxidizing upland soil cluster $\alpha$. Environ Microbiol 20:1016-1029. https://doi.org/10.1111/ 1462-2920.14036

Remans R, Beebe S, Blair M, Manrique G, Tovar E, Rao I, Croonenborghs A, Torres-Gutierrez R, El-Howeity M, Michiels J, Vanderleyden J (2008) Physiological and genetic analysis of root responsiveness to auxin-producing plant growth-promoting bacteria in common bean (Phaseolus vulgaris L.). Plant Soil 302:149-161. https://doi.org/10.1007/s11104-007-9462-7

Rohe L, Anderson T-H, Braker G, Flessa H, Giesemann A, LewickaSzczebak D, Wrage-Mönnig N, Well R (2014) Dual isotope and isotopomer signatures of nitrous oxide from fungal denitrification - a pure culture study. Rapid Commun Mass Spectrom 28:18931903. https://doi.org/10.1002/rcm.6975

Safronova VI, Piluzza G, Zinovkina NY, Kimeklis AK, Belimov AA, Bullitta S (2012) Relationships between pasture legumes, rhizobacteria and nodule bacteria in heavy metal polluted mine waste of SW Sardinia. Symbiosis 58:149-159. https://doi.org/10.1007/ s13199-012-0207-x

Sainju UM (2016) A Global Meta-Analysis on the Impact of Management Practices on Net Global Warming Potential and Greenhouse Gas Intensity from Cropland Soils Citation: Sainju UM (2016) A Global Meta-Analysis on the Impact of Management Practices on Net Global Warming Potential and Greenhouse Gas Intensity from Cropland Soils. PLoS ONE 11:148527. https://doi.org/10. 1371/journal.pone.0148527

Saunois M, Bousquet P, Poulter B, Peregon A, Ciais P, Canadell JG, Dlugokencky EJ, Etiope G, Bastviken D, Houweling S, JanssensMaenhout G, Tubiello FN, Castaldi S, Jackson RB, Alexe M, Arora VK, Beerling DJ, Bergamaschi P, Blake DR, Brailsford G, Brovkin V, Bruhwiler L, Crevoisier C, Crill P, Covey K, Curry C, Frankenberg C, Gedney N, Höglund-Isaksson L, Ishizawa M, Ito A, Joos F, Kim HS, Kleinen T, Krummel P, Lamarque JF, Langenfelds R, Locatelli R, Machida T, Maksyutov S, McDonald KC, Marshall J, Melton JR, Morino I, Naik V, O'Doherty S,
Parmentier FJW, Patra PK, Peng C, Peng S, Peters GP, Pison I, Prigent C, Prinn R, Ramonet M, Riley WJ, Saito M, Santini M, Schroeder R, Simpson IJ, Spahni R, Steele P, Takizawa A, Thornton BF, Tian H, Tohjima Y, Viovy N, Voulgarakis A, Van Weele M, Van Der Werf GR, Weiss R, Wiedinmyer C, Wilton DJ, Wiltshire A, Worthy D, Wunch D, Xu X, Yoshida Y, Zhang B, Zhang Z, Zhu Q (2016) The global methane budget 2000-2012. Earth Syst Sci Data 8:697-751. https://doi.org/10.5194/essd-8-697-2016

Scarlett K, Denman S, Clark DR, Forster J, Vanguelova E, Brown N, Whitby C (2021) Relationships between nitrogen cycling microbial community abundance and composition reveal the indirect effect of soil pH on oak decline. ISME J 15:623-635. https://doi. org/10.1038/s41396-020-00801-0

Schleper C, Nicol GW (2010) Ammonia-Oxidising Archaea - Physiology, Ecology and Evolution. Academic Press, Cambridge, United Kingdom, pp 1-41

Schnell S, King GM (1994) Mechanistic analysis of ammonium inhibition of atmospheric methane consumption in forest soils. Appl Environ Microbiol 60:3514-21

Shen W, Xue H, Gao N, Shiratori Y, Kamiya T, Fujiwara T, Isobe K, Senoo K (2020) Effects of copper on nitrous oxide (N2O) reduction in denitrifiers and $\mathrm{N} 2 \mathrm{O}$ emissions from agricultural soils. Biol Fertil Soils 56:39-51. https://doi.org/10.1007/ s00374-019-01399-y

Singh JS, Seneviratne G (2017) Agro-environmental sustainability. Springer International Publishing, Cham

Six J, Elliott ET, Paustian K (1999) Aggregate and soil organic matter dynamics under conventional and no-tillage systems. Soil Sci Soc Am J 63:1350-1358. https://doi.org/10.2136/sssaj1999.6351350x

Sohngen B, Tian X (2016) Global climate change impacts on forests and markets. For Policy Econ 72:18-26. https://doi.org/10.1016/j. forpol.2016.06.011

Song C, Jin K, Raaijmakers JM (2021) Designing a home for beneficial plant microbiomes. Curr Opin Plant Biol 62:102025. https://doi. org/10.1016/j.pbi.2021.102025

Srinivasarao C, Manjunath M (2017) Potential of beneficial bacteria as eco-friendly options for chemical-free alternative agriculture. In: Singh D, Singh H, Prabha R (Eds) Plant-Microbe Interactions in Agro-Ecological Perspectives. Springer Singapore, Singapore, pp 473-493

Steffen W, Rockström J, Richardson K, Lenton TM, Folke C, Liverman D, Summerhayes CP, Barnosky AD, Cornell SE, Crucifix M, Donges JF, Fetzer I, Lade SJ, Scheffer M, Winkelmann R, Schellnhuber HJ (2018) Trajectories of the Earth System in the Anthropocene. Proc Natl Acad Sci U S A 115:8252-8259

Tahat MM, Alananbeh KM, Othman YA, Leskovar DI (2020) Soil Health and Sustainable Agriculture Sustain 12:1-26. https://doi. org/10.3390/SU12124859

Tate KR (2015) Soil methane oxidation and land-use change - from process to mitigation. Soil Biol Biochem 80:260-272

R Core Team (2018) R: A language and environment for statistical computing. R Foundation for Statistical Computing, Vienna, Austria. URL https://www.R-project.org/

Tian H, Lu C, Ciais P, Michalak AM, Canadell JG, Saikawa E, Huntzinger DN, Gurney KR, Sitch S, Zhang B, Yang J, Bousquet P, Bruhwiler L, Chen G, Dlugokencky E, Friedlingstein P, Melillo J, Pan S, Poulter B, Prinn R, Saunois M, Schwalm CR, Wofsy SC (2016) The terrestrial biosphere as a net source of greenhouse gases to the atmosphere. Nature 531:225-228. https://doi.org/10. 1038/nature 16946

Tveit AT, Hestnes AG, Robinson SL, Schintlmeister A, Dedysh SN, Jehmlich N, Von Bergen M, Herbold C, Wagner M, Richter A, Svenning MM (2019) Widespread soil bacterium that oxidizes atmospheric methane. Proc Natl Acad Sci U S A 116:8515-8524. https://doi.org/10.1073/pnas.1817812116 
Van Kessel MAHJ, Speth DR, Albertsen M, Nielsen PH, Op Den Camp HJM, Kartal B, Jetten MSM, Lücker S (2015) Complete nitrification by a single microorganism Europe PMC Funders Group. Nature 528:555-559. https://doi.org/10.1038/nature16459

Veldkamp E, Koehler B, Corre MD (2013) Indications of nitrogenlimited methane uptake in tropical forest soils. Biogeosciences 10:5367-5379. https://doi.org/10.5194/bg-10-5367-2013

Vessey JK (2003) Plant growth promoting rhizobacteria as biofertilizers. Plant Soil 255:571-586. https://doi.org/10.1023/A:10260 37216893

Yamamoto A, Akiyama H, Nakajima Y, Hoshino YT (2017) Estimate of bacterial and fungal $\mathrm{N} 2 \mathrm{O}$ production processes after crop residue input and fertilizer application to an agricultural field by $15 \mathrm{~N}$ isotopomer analysis. Soil Biol Biochem 108:9-16. https://doi.org/ 10.1016/j.soilbio.2017.01.015
Yao H, Gao Y, Nicol GW, Campbell CD, Prosser JI, Zhang L, Han W, Singh BK (2011) Links between ammonia oxidizer community structure, abundance, and nitrification potential in acidic soils. Appl Environ Microbiol 77:4618-4625. https://doi.org/10.1128/ AEM.00136-11

Yin Q, Gu M, Wu G (2020) Inhibition mitigation of methanogenesis processes by conductive materials: a critical review. Bioresour Technol 317:123977. https://doi.org/10.1016/j.biortech.2020. 123977

Publisher's Note Springer Nature remains neutral with regard to jurisdictional claims in published maps and institutional affiliations. 